Portland State University

PDXScholar

8-8-1996

\title{
Evaluation of a Rapid-screening Toxicity Test Using the Ciliate, Colpoda inflata (Stokes): Sensitivity and Bioavailability to Model Compounds
}

Daria Galina Mochan

Portland State University

Follow this and additional works at: https://pdxscholar.library.pdx.edu/open_access_etds

Part of the Biology Commons

Let us know how access to this document benefits you.

\section{Recommended Citation}

Mochan, Daria Galina, "Evaluation of a Rapid-screening Toxicity Test Using the Ciliate, Colpoda inflata (Stokes): Sensitivity and Bioavailability to Model Compounds" (1996). Dissertations and Theses. Paper 5165.

https://doi.org/10.15760/etd.7041

This Thesis is brought to you for free and open access. It has been accepted for inclusion in Dissertations and Theses by an authorized administrator of PDXScholar. Please contact us if we can make this document more accessible: pdxscholar@pdx.edu. 


\section{THESIS APPROVAL}

The abstract and thesis of Daria Galina Mochan for the Master of Science degree in

Biology were presented 8 August 1996 and accepted by the thesis committee and the department.

COMMITTEE APPROVALS:
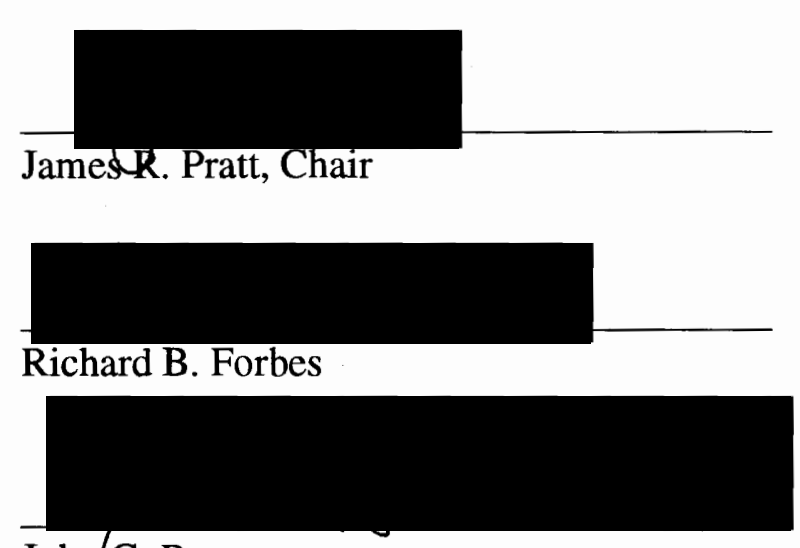

JohnlG. Rueter

DEPARTMENT APPROVAL:
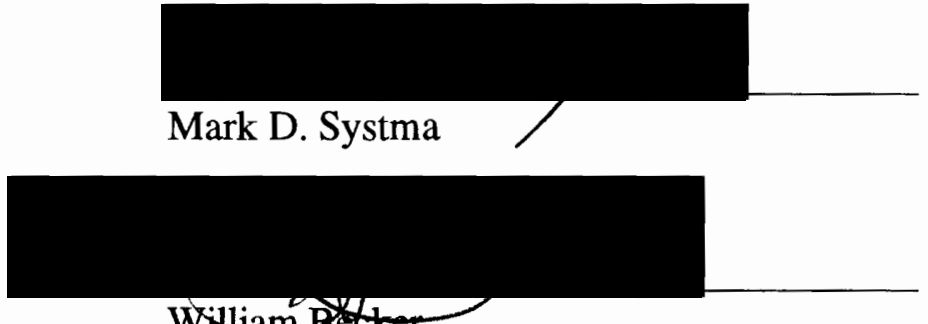

William Bceker

Representative of Office of Graduate Studies

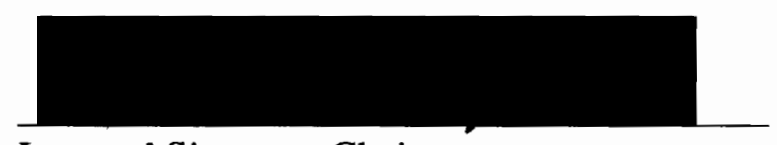

Leonard Simpson, Chair

Department of Biology

$* * * * * * * * * * * * * * * * * * * * * * * * * * * * * * * * * * * * * * * * * * * * * * * * * * * * * * * * * * * * * * * * * * * * *$

ACCEPTED FOR PORTLAND STATE UNIVERSITY BY THE LIBRARY

by

on

7 Petact 199 


\begin{abstract}
An abstract of the thesis of Daria Galina Mochan for the Master of Science in Biology presented 8 August 1996.
\end{abstract}

Title: Evaluation of a rapid-screening toxicity test using the ciliate, Colpoda inflata (Stokes): sensitivity and bioavailability to model compounds.

Standard toxicity tests often require high costs for maintaining healthy cultures, so few test species are employed in routine ecotoxicological analysis. An alternative is the "battery of tests" approach involving using rapid toxicity tests for screening. Rapid-screening toxicity tests must display organism sensitivity, similarity in responses to other test organisms, relevancy to many circumstances, and repeatability. Protozoa are ideal candidates for rapid-screening bioassays. They are cosmopolitan, play important roles in ecosystems, and have high reproductive rates. Many protozoa can form a resting stage (cyst) that remains viable during adverse conditions, eliminating the need for maintaining continuous cultures for testing.

The main objective of this research was to evaluate the soil ciliate, Colpoda inflata (Stokes), as a bioassay organism in rapid-screening tests by determining its sensitivity to a variety of model compounds. These tests were based on the principle that exposure to a toxic compound would negatively affect population growth. To test for sensitivity, $C$. inflata was exposed to different levels of dissolved organic carbon in 
test media for each compound tested. $C$. inflata was expected to be more sensitive to toxicants in an inorganic medium than in media with high organic carbon content. Data were analyzed by determining the median tolerance limit for inhibition of population growth (IG50) relative to controls. IG50 values of the eight model compounds tested varied considerably. $C$. inflata growth was not significantly affected by 2,4-D or malathion. $C$. inflata showed differences in sensitivity between organic and inorganic media for the toxic metals tested and the order of toxicity corresponded to those found in standard tests. A significant difference occurred between the test media and the pesticide PCP, where growth was not inhibited in the organic medium; in the inorganic medium the IG50 was $0.269 \mathrm{mg} / \mathrm{L}$. No significant effect of test media was found for ammonia or SDS. Compared to several published toxicity results, $C$. inflata proved more sensitive overall than other rapid-screening tests and many standard acute toxicity tests. Results of this study show that this rapid-screening toxicity test is sensitive, repeatable, and provides information similar to traditional standard toxicity tests. 
EVALUATION OF A RAPID-SCREENING TOXICITY TEST

USING THE CILIATE, COLPODA INFLATA (STOKES):

SENSITIVITY AND BIOAVAILABILITY TO MODEL COMPOUNDS

by

DARIA GALINA MOCHAN

A thesis submitted in partial fulfillment of

the requirements for the degree of

\section{MASTER OF SCIENCE \\ in \\ BIOLOGY}

Portland State University

1996 


\section{TABLE OF CONTENTS}

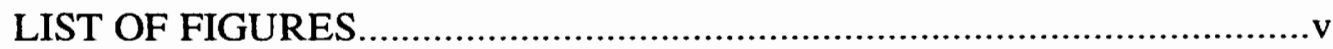

LIST OF TABLES .................................................................................

ACKNOWLEDGEMENTS............................................................... vii

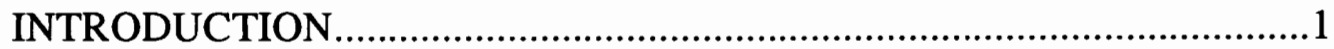

Rapid-screening toxicity testing..............................................

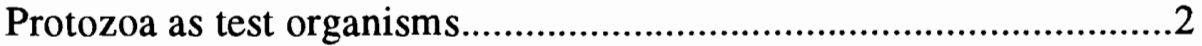

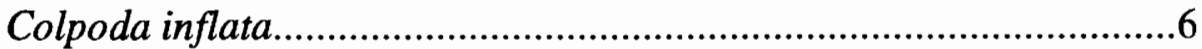

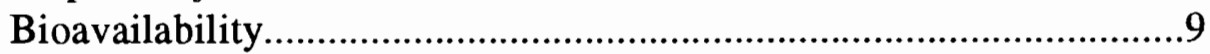

Objectives........................................................................ 11

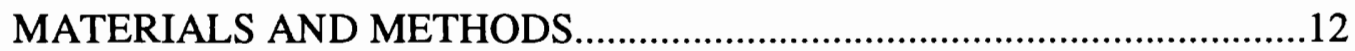

Test principle............................................................................ 12

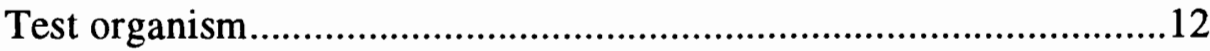

Test compounds......................................................................... 12

Media preparation....................................................... 12

Stock preparation...........................................................13

Toxicant verification and waste disposal................................15

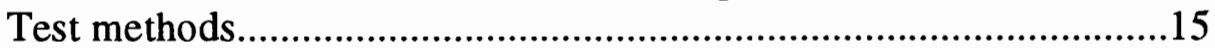

Culturing.................................................................. 15

Cell enumeration...............................................................16

Initiating a test................................................................16

Data analysis............................................................. 17

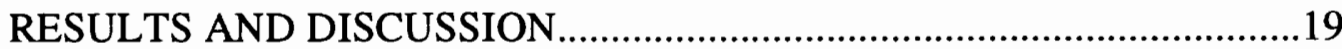

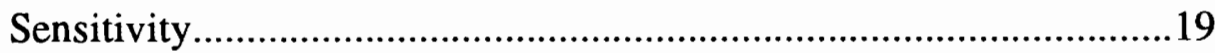

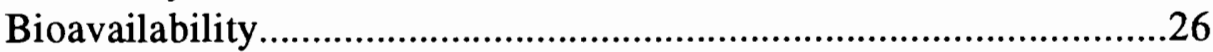

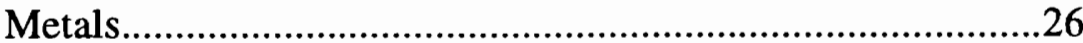

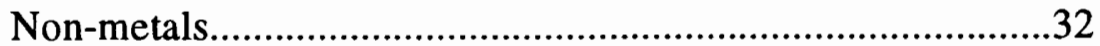

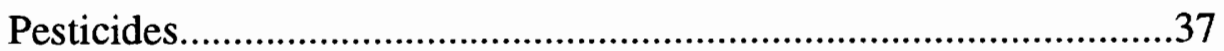

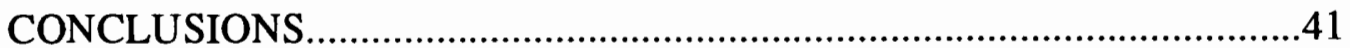

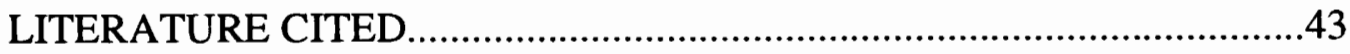

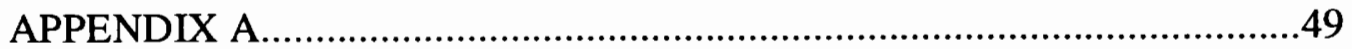

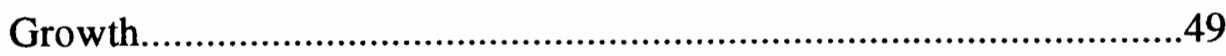

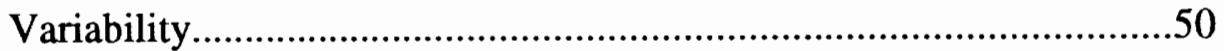

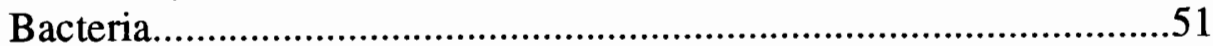

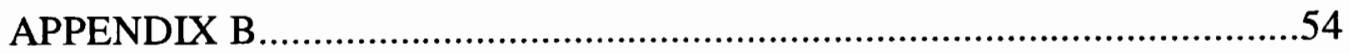




\section{LIST OF FIGURES}

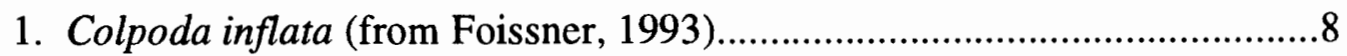

2. Average relative sensitivity rank of rapid-screening and standard acute toxicity tests

3. Dose-response curve illustrating the effects of cadmium on growth of $C$. inflata tested in organic and inorganic media.

4. Dose-response curve illustrating the effects of copper on growth of $C$. inflata tested in organic and inorganic media..

5. Dose-response curve illustrating the effects of zinc on growth of $C$. inflata tested in organic and inorganic media.

6. Dose-response curve illustrating the effects of SDS on growth of $C$. inflata tested in organic and inorganic media.

7. Dose-response curve illustrating the effects of un-ionized ammonia on growth of $C$. inflata tested in organic and inorganic media. 


\section{LIST OF TABLES}

1. Prepared and measured stock concentrations of eight compounds...............14

2. Sensitivity of C.inflata to eight compounds in $24 \mathrm{hr}$ tests. Ranges of standard acute toxicity tests and water quality criteria (USEPA, 1986).

3. EC50/LC50 values of several species of protozoa.................................21

4. LC50/EC50 endpoints of several rapid and standard toxicity tests currently being utilized (from Toussaint et al., 1995).

5. Effects of six compounds on $C$. inflata growth in organic and inorganic media. 


\section{ACKNOWLEDGEMENTS}

Funding for this research was provided by grant no. DAMD17-95-1-5068 from the U.S. Army Biomedical Research and Development Command, Fort Detrick, Maryland.

I am indebted to my advisor, J.R. Pratt, who has given me guidance and advice since I was an undergraduate. Zhenkang Xu and Nancy Bowers provided advice with technical issues on this research as well as serving as laboratory companions and friends. Sara Carlsen was nice enough to count the bacteria for this test. I am extremely appreciative of all of my friends, on both sides of the country, who have supported me thru letters, email, or just lended an ear. Particularly, I wish to acknowledge Rich Mitchell, Bill Hall and Ian Waite for continuously 'being there'. Special thanks go to David Huff who provided countless hours of conversation and company. My grandparents, Arthur and Clara May Pawlowski, have sent me a constant stream of letters, always filled with encouraging words. Lastly, I'd like to thank both my parents, Bonnie and Eugene, and my sister Kara, for their unending support of their daughter/sibling who moved more than 3,000 miles away to study something that did not directly involve people.

This research is dedicated to the ciliates who gave their lives for the advancement of science. 


\section{INTRODUCTION}

\section{Rapid screening toxicity testing}

Research in environmental toxicology has been primarily driven by legislation. There are over 63,000 chemicals in common use with 3,000 compounds accounting for approximately $90 \%$ of the total (Maugh, 1983). Many laws require toxicity testing and toxicological assessments of compounds, effluents, discharge, or hazard waste sites. No man-made instrument can measure the toxicity of a substance to a biological organism, thus biological assays (bioassays) are necessary to estimate biological risk (Cairns, 1986; Cairns and Pratt, 1989).

Bioassays are used for regulatory purposes for several different reasons. Tebo (1985) distinguished three main purposes: screening, establishing limitations, and monitoring. At the screening level, tests should be rapid, sensitive, relevant and costefficient. Establishing limitations requires that the tests should be precise with respect to possible contamination levels and applicable to many conditions. Monitoring tests are expected to be rapid, sensitive, precise and cost-efficient.

Many different kinds of standard bioassays are currently employed. Standard test protocols include both acute and chronic toxicity, with the most common endpoint in acute toxicity being death (median lethal concentration, LC50). Standard aquatic test organisms include the green alga, Selenastrum capricornutum, invertebrates such as Daphnia magna and Ceriodaphnia dubia (cladocerans), and several fish species, 
including Lepomis macrochirus (blue-gill sunfish), Onchorhynchus mykiss (rainbow trout), and Pimephales promelas (fathead minnow). This list of standard tests organisms does not represent many taxonomic groups, such as insects, bacteria, protozoa, which are abundant in the environment. Also, these tests ignore soil fauna. Organisms are chosen with the idea that they are the most sensitive indicators for their environment, which many researchers have argued is not a valid assumption (Kimball and Levin, 1985; Cairns, 1986).

Because a few single species tests may not adequately represent all environments, a "battery of tests" approach has been proposed for assessing the biological effects of contaminants in the environment (Schaeffer, 1994; Toussaint et. al, 1995). Standard tests often represent an unnecessary expenditure of resources. Thus, many alternative tests have been suggested for contaminant screening because of their simplicity, reproducibility, shorter exposure time, low cost, and increased sensitivity (Elnabarawy et. al., 1988; Snell and Persoone, 1989; Janssen and Persoone, 1993; Toussaint et. al 1995). Rapid toxicity tests are intended to be used in circumstances where screening of large numbers of samples for possible toxic effects is needed prior to definitive testing.

\section{Protozoa as test organisms}

Standard test species span a wide variety of organisms, from bacteria to fish and other vertebrates. However, the larger and more 'complex' the test organism, the more care, cost, and time needed to maintain healthy cultures (Sprague, 1973; APHA, 1989). 
The test species used must be representative of the system and region tested (Landis and Yu, 1995). The common use of the cladoceran, Daphnia magna, to test compounds intended for the soil would not accurately depict possible effects to soil organisms. Using a cold water fish (such as a rainbow trout) to test in a region where only warm water streams occur presents another problem. In addition, special licenses are often required to conduct testing (especially with vertebrates). Therefore, bioassay organisms must be chosen using many criteria.

Protozoa are ideal candidates for environmental toxicity testing. They are small and easily cared for, saving time and resources. This is especially true when compared to organisms such as fish, for which much time and money are spent maintaining healthy stock cultures. Many protozoa form a resting stage (cyst), eliminating the necessity for constant culturing and allowing organisms to be stored until needed. The rapid growth rate of protozoa allows the effects of a compound to be assessed using an array of variables (such as reproduction, feeding, metabolism, respiration rates, etc.) in a relatively short period of time compared to other bioassay organisms (Cairns, 1974). Because of their rapid growth rate and relatively delicate nature protozoa generally react to environmental contaminants faster than other eukaryotic organisms (Foissner, 1994). In addition, most protozoa are capable of both sexual and asexual reproduction which would result in a large culture of nearly uniform genetic makeup (Cairns, 1974: Landis and $\mathrm{Yu}, 1995)$. 
The large diversity, biomass, and production of protozoans makes them important components of both aquatic and soil ecosystems. In aquatic systems, protozoa are responsible for consumption of algae and bacteria and are essential components of the microbial loop (Fenchel, 1988). As a principal consumer of bacteria, soil protozoa (especially ciliates) help regulate and modify the size and constitution of the bacterial community (Stout, 1980). This subsequently accelerates the turnover of the soil biomass and thus the turnover of soil organic matter. Any changes in community structure and production would greatly influence higher trophic levels as well as nutrient cycling (Fenchel, 1988).

Many species of protozoa are cosmopolitan, allowing easy comparison of results from several regions and different natural systems. Protozoa may be abundant in habitats which may lack higher organisms due to extreme environmental conditions (e.g., Antarctic soils, ephemeral ponds, plant foliage, etc.). While these areas may lack higher life, man-made contaminants may exist. The eukaryotic origin of protozoa makes them comparable to metazoans, and their reactions to compounds can more convincingly be related to higher organisms than can those of the prokaryotes (Foissner, 1994). Protozoan tolerance levels are neither more nor less sensitive than those of metazoans. Lastly, special collecting/testing permits are generally not necessary.

While there are strong arguments for using protozoa as bioassay organisms, a few factors dissuade their use. Protozoa are usually inconspicuous and not detectable to 
the naked eye, thus requiring the use of microscopes for identification or counting (Foissner, 1994). The large number of species often requires special training in identification. In addition, many species have not been thoroughly investigated and little or none of their ecological background is known. These factors make identification of protozoan communities a time-consuming task and supplying the needs of the culture somewhat difficult. Culturing difficulties can be mitigated, however, by using a single strain obtained through a 'library' such as the American Type Culture Collection. Responses of protozoa, like those of standard test species, cannot be directly compared to human responses or to the tolerance of an entire natural system. Finally, despite their undisputed importance in the functioning of the world's ecosystems, protozoa receive little public attention, making funding scarce.

While the use of protozoa to assess toxicity is not new, relatively few studies have been conducted. Bioassay organisms include Tetrahymena pyriformis (e.g., Yoshioka, et al., 1985; APHA, 1989; Roberts and Berk, 1993), Tetrahymena thermophila (Pauli et al., 1993), Entosiphon sulcatum (Bringmann and Kuhn, 1980), Spirostomum ambiguum (Nalecz-Jawecki et al., 1993), Colpoda cucculus (Janssen et al., 1995), Colpoda stenii (Forge et al., 1993) and Colpidium campylum (e.g., Dive et al., 1980; Dive et al., 1982; Dive et al., 1989; Le Du et al., 1993). Methods used for protozoan bioassays differ considerably. Endpoints measured include lethality, (Ruthven and Cairns, 1973), chemoattraction (Roberts and Berk, 1993) and deformation (Nalecz-Jawecki et al., 1993). The most common method is the 
assessment of growth inhibition based on population density. Several of these tests, including all tests conducted with $C$. campylum, were based on counting populations by means of an electronic cell counter (e.g., a Coulter Electronic Particle Counter; Gray and Ventilla, 1973; Dive et al., 1989). Others, such as the T. pyriformis (the only protozoan test in Standard Methods, APHA, 1989) used change in absorbence measured with a spectrophotometer) as an indication of effects of compounds. Counting has also been performed manually by microscopy (Forge et al., 1993; Janssen et al., 1995). Protozoan bioassays have been used to test the effects of many compounds including: pesticides (Dive et al., 1980; Schreiber and Brink, 1989), metals (Rutheven and Cairns, 1973; Dive et al., 1982), oils and detergents (Rogerson and Berger, 1981) and a variety of compounds and mixtures (e.g., sewage sludge and effluent). Because methods were sometimes drastically different, few generalizations can be made concerning the sensitivity of individual species or tests. However, it appears that protozoan bioassays display varying responses to different chemicals within and between species (Ruthven and Cairns, 1973; Dive et al, 1980; NaleczJawecki et al., 1993).

\section{Colpoda inflata}

Relatively little environmental research has been conducted on Colpoda inflata (Stokes), (Protozoa: Ciliophora), the ciliate protozoan used in this research. It appears to be cosmopolitan, its presence having been documented in many countries (Foissner, 
1993). Genetic analysis of strains reveal no significant differences among $C$. inflata from fifteen different locations spanning biogeographic regions (Bowers and Pratt, 1995). Cells range in size from $30-90$ um, but always display a characteristic L- shape (Figure 1). C. inflata feeds almost entirely on bacteria, but has also been observed to consume small flagellates (Foissner, 1993; Foissner and Berger, 1996). While $C$. inflata can inhabit both freshwater and soil, it is more commonly associated with terrestrial habitats and is generally accepted to be a soil protozoan (Foissner, 1993). Consequently, it displays features common to other terrestrial protozoa.

Soil protozoa must be able to adapt to the flux of moisture in their environment. Loss of water due to evaporation and evapotranspiration increases the relative concentration of salts, producing osmotic stress. Heavy or extended precipitation may cause dilution stress and create anaerobic conditions by filling available airspaces between soil particles (Fenchel, 1988). A survival trait of most soil protozoa is the ability to produce resting stages, which allow the cell to remain viable within temporary sheath. Resistant cysts are formed when environmental conditions become unfavorable (e.g., decreased availability of a food source, reduced oxygen, desiccation, change in $\mathrm{pH}$, etc.). When environmental conditions improve, soil protozoa will excyst (i.e., return to active form). The time of excystment is variable, but some research has shown that there is an inverse relationship between the amount of time a soil protozoan remains in a resting cyst and the amount of time it will take to excyst (Loussier and 


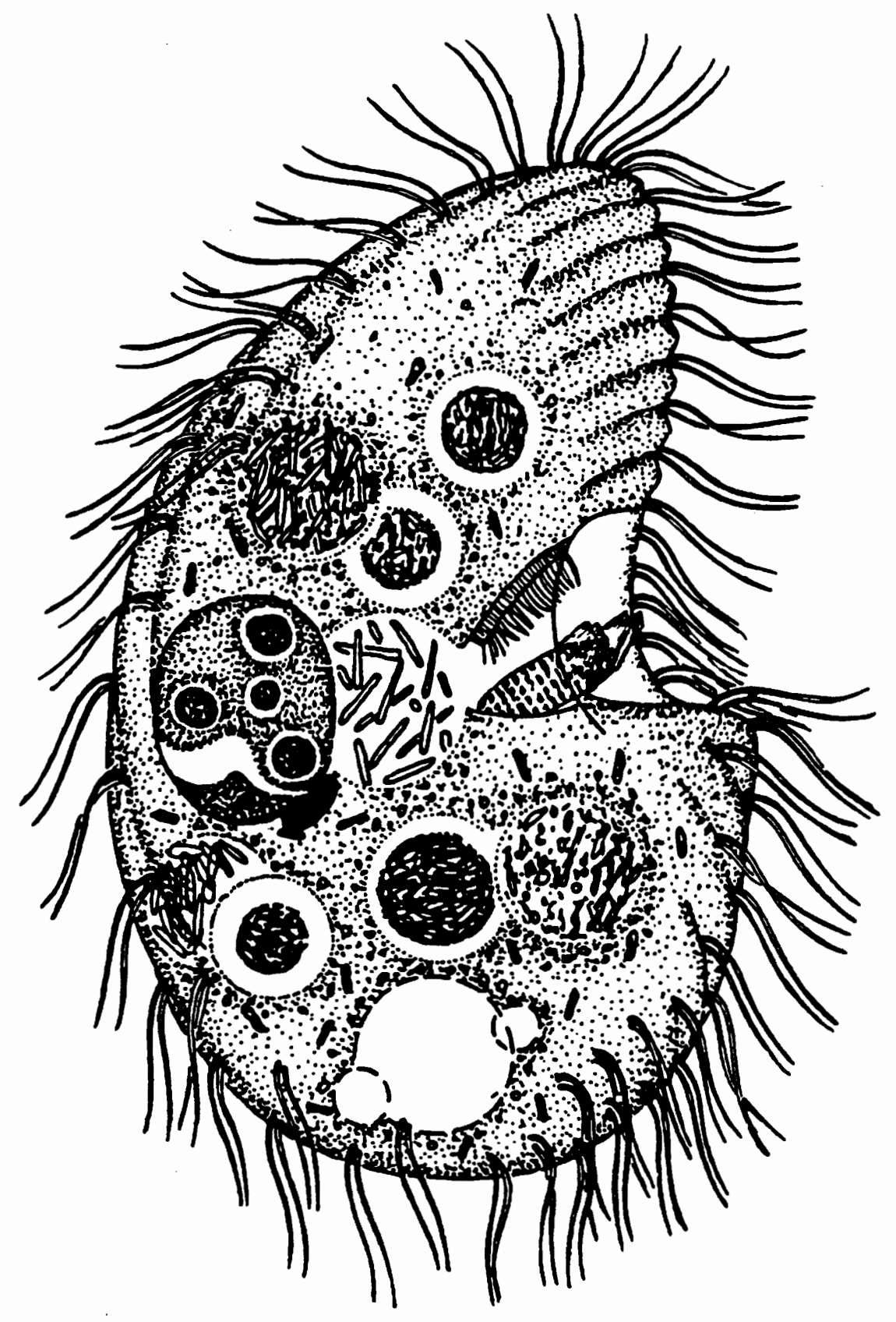

Figure 1. Colpoda inflata (from Foissner, 1993). 
Bamforth, 1990). Initial studies with $C$. inflata have shown that excystment rate is extremely variable (Zhenkang Xu, pers. comm).

Sexual reproduction has never been documented in $C$. inflata (Foissner, 1993). Instead, these ciliates reproduce asexually by binary fission. In $C$. inflata, two consecutive divisions occur within special reproductive cysts (which generally have thinner walls than resting cysts). These divisions are transverse (i.e., occur at right angles) and produce 4 viable cells. Studies have found that the generation time at 15 ${ }^{\circ} \mathrm{C}$ is 6.2 hours and at 2.6 hours at $30^{\circ} \mathrm{C}$ (Foissner, 1993).

\section{Bioavailability}

Organic substances in the environment often influence the solubility, mobility, persistence and toxicity of contaminants. Natural organic substances are derived from decomposition of dead organisms, animal wastes, and microbial byproducts. The term bioavailable refers to the proportion of a compound in the environment that may be taken up by an organism (Cockerham and Shane, 1994). Compounds may bind to dissolved complexes, sediments, or organic films, therefore potentially decreasing their availability to organisms and, therefore, their toxicity. However, there is a lack of quantitative data to explain this phenomenon and unfortunately almost no predictive capability currently exists to forecast bioavailability without large uncertainty (Depledge et al., 1994). Sensitive and biologically accurate models are desperately 
needed to discriminate toxicity caused by binding of organic material (Jenne and Zachara, 1987).

Protozoa are often found in environments that contain a large amount of organic material (e.g., dissolved organic carbon (DOC)). Natural concentrations of DOC in streams and rivers can be as high as $50 \mathrm{mg}$ carbon/L in waters (Stumm and Morgan, 1996). DOC has been shown to alter toxicity of several metals (Depledge et al., 1994) as well as decomposition rates of certain pesticides (Perdue and Wolfe, 1982). Most protozoan culture media also contains high amounts of DOC, usually to grow the bacterial food source. Inorganic media would require the constant addition of a food supply (i.e., bacteria), since few protozoa can be cultured axenically. While higher organisms are often tested and cultured in "natural" media (i.e., well water, reconstituted water), to test for bioavailability would take a significantly longer time than it would for a protozoan bioassay. Dive et. al. (1982) found the ciliate, Colpidium campylum, can be used to detect cadmium complexation to humic material as a measured by differential population growth. They found that both toxicity and complexation of cadmium are highly correlated to medium composition. Yoshioka et al. (1985) suggested that the composition of the test medium used to grow Tetrahymena pyriformis could alter the toxicity of a given compound. Therefore the use of ciliates to evaluate bioavailability of compounds is promising. 


\section{Objectives}

There were two main objectives for this research.

1) Investigate the use of the ciliated protozoan, Colpoda inflata, as a bioassay organism by determining its sensitivity to a variety of model compounds.

2) Assess effects of media on bioavailability by using organic and inorganic media to compare sensitivity to model contaminants.

Test methods emphasized simplicity in order to fulfill the definition of rapidscreening tests and to also allow its practical use as a semi-field toxicity test in the future. 


\section{MATERIALS AND METHODS}

\section{Test Principle}

These toxicity tests are based on the principle that toxicity of a compound will negatively affect population growth of the soil ciliate, $C$. inflata. Estimates of toxicity using growth rates are based on growth in controls. Normal growth rates are relatively high (3-4 doublings per day) and the cells are large enough to be counted accurately under low magnification (40-80x). A test involves inoculating medium and toxicant to a fixed number of cells and counting cells after 24 hours. Toxicity is then inferred by difference in cell number across doses (i.e., difference in growth rate). These tests are an ideal candidate for a rapid screening of toxicants.

\section{Test organism}

The strain of $C$. inflata used in this research was obtained as dry cysts from the American Type Culture Collection (ATCC 30917, Rockville, MD, USA). A nonpathogenic strain of the bacterium Klebsiella pnemoniae (ATCC 27889) was used as a food source in the inorganic media.

\section{Test compounds}

Media preparation. To assess the effects of media type on various compounds, two media classes (inorganic and organic) were used in the $C$. inflata experiments. The 
inorganic minimal salt medium (6 mg KCL, $4 \mathrm{mg} \mathrm{CaHPO}, 2$ mg MgSO $4,1 \mathrm{~L}$ deionized distilled water $\left(\mathrm{ddH}_{2} \mathrm{O}\right)$; Prescott and James, 1955) was sterilized before each use. The organic medium, Sonneborn's Paramecium Medium, was prepared by boiling $2.5 \mathrm{~g}$ Cerophyll for 5 minutes in $1 \mathrm{~L} \mathrm{ddH_{2 }} \mathrm{O}$, filtered through \#1 Whatman filter paper buffered with $0.5 \mathrm{~g} \mathrm{Na}_{2} \mathrm{PO}_{4}$, and autoclaved. Full strength Sonneborn's was dilluted to a final concentration of $10 \%$ and $5 \%$. All compounds were tested using both minimal salts medium and $10 \%$ Sonneborn's. Final averaged $\mathrm{pHs}$ of minimal salts and $10 \%$ Sonneborn's were 5.5 and 6.8 , respectively. Three compounds (the metals) were also tested with 5\% Sonneborn's .

Stock preparation. Eight compounds were tested: ammonia (as $\left.\left(\mathrm{NH}_{4}\right)_{2} \mathrm{SO}_{4}\right)$, cadmium (as $3 \mathrm{CdSO}_{4} \cdot 8 \mathrm{H}_{2} 0$ ), copper (as $\mathrm{CuSO}_{4} \cdot 5 \mathrm{H}_{2} \mathrm{O}$ ), 2,4-dichlorophenoxyacetic acid (2,4-D), malathion, pentachlorophenol (PCP), sodium dodecyl sulfate (SDS as laural sulfate) and zinc (as $\mathrm{ZnSO}_{4} \cdot 7 \mathrm{H}_{2} 0$ ) (Table 1). Chemical sources included: J.T. Baker Inc. (ammonium sulfate, cadmium, copper), Cheminova, Inc. (malathion), Mallinckrodt Chemical Works (zinc), Rhone-Poulenc, Inc. (2,4-D) and Sigma Chemical Company (PCP, SDS). Cadmium, copper, and zinc were prepared with $\mathrm{ddH}_{2} \mathrm{O}$; malathion, PCP, 2,4-D, ammonia and SDS were prepared using both sterilized minimal salts and 10\% Sonneborn's media. Prepared stock concentrations are listed in Table 1. Final stocks of malathion, PCP, un-ionized ammonia, and SDS did not need pH adjustments. The $\mathrm{pH}$ of the 2,4-D stock made with minimal salts medium was adjusted with $0.15 \mathrm{NaOH}$. No carrier solvents were used. 
Table 1. Prepared and measured stock concentrations (in $\mathrm{mg} / \mathrm{l}$ ) of eight compounds.

Analytical methods of analysis chosen by Coffey Laboratories, Inc.

\begin{tabular}{|c|c|c|c|}
\hline Compound & $\begin{array}{l}\text { Prepared } \\
\text { concentration }\end{array}$ & $\begin{array}{l}\text { Actual } \\
\text { concentration }\end{array}$ & Analytical method \\
\hline \multirow[t]{3}{*}{ Ammonia (as $\left.\left(\mathrm{NH}_{4}\right)_{2} \mathrm{SO}_{4}\right)$} & 1000 & 670 & SM 4500, A-D \\
\hline & & un-ionized= & \\
\hline & & 0.0944 & \\
\hline \multirow[t]{2}{*}{ Cadmium (as $3 \mathrm{CdSO}_{4} \cdot 8 \mathrm{H}_{2} \mathrm{O}$ ) } & 1 & 0.72 & CFR 200.7 \\
\hline & 5 & 6.5 & \\
\hline \multirow[t]{2}{*}{ Copper (as $\left.\mathrm{CuSO}_{4} \cdot 5 \mathrm{H}_{2} \mathrm{O}\right)$} & 5 & 5.4 & CFR 200.7 \\
\hline & 50 & 51 & \\
\hline 2,4-dichlorophenoxyacetic & 600 & 280 & EPA 615 \\
\hline \multicolumn{4}{|l|}{$\operatorname{acid}(2,4-D)$} \\
\hline Malathion & 140 & 120 & EPA 614 \\
\hline Pentachlorophenol (PCP) & 14 & 2 & CFR 604 \\
\hline Sodium Dodecyl Sulfate & 1000 & 1100 & CFR 200.7 \\
\hline \multicolumn{4}{|l|}{ (SDS) (as laural sulfate) } \\
\hline \multirow[t]{2}{*}{$\mathrm{Zinc}\left(\right.$ as $\left.\mathrm{ZnSO}_{4} \cdot 7 \mathrm{H}_{2} \mathrm{O}\right)$} & 10 & 11 & CFR 200.7 \\
\hline & 100 & 110 & \\
\hline
\end{tabular}


Toxicant verification and waste disposal. For each compound tested, toxicant concentration of primary and secondary stocks was independently verified by Coffey Laboratories, Inc. (a certified analytical laboratory). Table 1 lists the estimated stock concentrations and actual stock concentrations based on methods listed. Chemical preservation procedures followed the recommendations of Coffey Laboratories, and were based on the specific compound used. Analytical methods employed are briefly described in appendix B. Waste disposal followed normal Portland State University procedures (disposal through Environmental Health and Safety).

\section{Test Methods}

Culturing. The food bacterium, $K$. pnemoniae, was cultured on Bacto Nutrient Agar plates (APHA, 1989) at room temperature. After adequate growth (less than a week), the bacteria were scraped from the plates and placed in microcentrifuge tubes. These tubes were then placed in the freezer until needed. The day of the test, the tube of $K$. pnemoniae was taken out of the freezer and warmed at room temperature. A small quantity (approximately $10 \mathrm{mg}$ ) of bacteria was taken from the tube, placed in a small plastic beaker and weighed. Approximately $20 \mathrm{ml}$ of minimal salts medium was added to the beaker, which was subsequently covered with parafilm and vigorously vortexed. After adequate mixing, minimal salts media was added slowly to the bacterial solution and optical densities are taken after each addition. Previous experimentation determined ample bacteria for ciliate growth was at an absorbence of approximately 
0.2 at $400 \mathrm{~nm}$. At this absorbence, the bacterial density is $3.2 \times 10^{7}$ cells per ml. (Appendix A).

To begin a culture, the $C$. inflata cysts were inoculated in sterile 12-well polystyrene tissue culture plates (Costar, Inc.) with $2.5 \mathrm{ml} 10 \%$ Sonneborn's medium and incubated at $25^{\circ} \mathrm{C}$. Once cysts hatch, culture wells were subsampled daily to keep population in exponential growth and also to remove waste and add new medium.

Cell enumeration. Subsamples of wells with large populations were removed with a disposable transfer pipette and placed into $20-\mathrm{ml}$ scintillation vials. The culture was then mixed and $20 \mu \mathrm{l}$ withdrawn with an automatic micropipettor and dispensed via 4-6 drops on a clean microscope slide. Using a stereo microscope (magnification 40-80x) the total number of $C$. inflata cells in $20 \mu \mathrm{l}$ were estimated by counting each drop. This $20 \mu \mathrm{l}$ count was repeated at least three times. If counts varied by more than $20 \%$, improper mixing may have occurred and the process was repeated. When the average number of cells per $20 \mu \mathrm{l}$ was determined, the number of cells per $\mathrm{ml}(1000 \mu \mathrm{l})$ of culture was calculated by multiplying the average $20 \mu \mathrm{l}$ count by 50 .

Initiating a test. A single test consisted of 4 replicates of 6 treatments for a total of 24 individual experimental units. Treatment concentrations were arranged logarithmically and the volumes of culture, medium, and toxicant were determined before each experiment (total well volume is $2 \mathrm{ml}$ ). Stock culture density was determined (method described previously) so that a constant number of cells (approximately 200) were placed in each well. Once the culture volume was 
determined (culture volume never exceeded $200 \mu \mathrm{l}$ ), volumes of media and toxicants were calculated. For tests with the inorganic media, a constant volume of bacteria $(200 \mu \mathrm{l})$ was added to every well in test performed. Medium and bacteria for the minimal salts medium were carefully added to each well of a 24-well polystyrene tissue culture plate. The previously determined aliquots of well mixed culture were distributed next. The toxicant was added last, at which point the test began. After test initiation, the plate was incubated at $25^{\circ} \mathrm{C}$ for 24 hours $( \pm 2 \mathrm{hr})$. At the end of the test period, the density of cells in each replicate well was estimated by cell enumeration.

Data analysis. Data were analyzed in several ways. The endpoint examined was the density of $C$. inflata cells at the end of a test period. Cell densities were compared using a single factor analysis of variance test (6 treatments, 4 replicates per treatment). Dunnett's test was used to determine responses which were significantly different from the control (Dunnett, 1955).

Data also were examined by identifying the median tolerance limit for population growth, defined as the concentration corresponding to a 50\% inhibition of growth (IG50) relative to controls. This was accomplished by linear regression and inverse prediction (Sokal and Rohlf, 1995), estimating the IG50 from the control response where control mean is $100 \%$. Only the data from linear section of the doseresponse relationship were analyzed (i.e treatments higher than the lowest concentration of zero growth were discarded). Estimates of final treatment concentrations were extrapolated based on measured stock concentrations given by 
Coffey Laboratories, Inc. IG50s were considered statistically different if their 95\% confidence intervals did not overlap. 


\section{RESULTS AND DISCUSSION}

Each compound was tested in duplicate with a total of 48 test wells (40 dosed, 8 control wells). Tests of a single compound were conducted on the same day, thus using the same protozoa and bacteria cultures and stocks of both the compound and the media.

\section{Sensitivity}

C. inflata displayed varying sensitivity to the eight compounds tested (Table 2). Values calculated for IG50s ranged from $0.020 \mathrm{mg} / \mathrm{L}$ to $>231 \mathrm{mg} / \mathrm{L}$. Of the eight compounds evaluated, two pesticides (2,4-D and malathion) did not significantly inhibit C. inflata growth at the highest concentrations tested. The rank order of sensitivity in the minimal salts medium was: un-ionized ammonia $>\mathrm{Cd}>\mathrm{Cu}>\mathrm{Zn}>\mathrm{PCP}>\mathrm{SDS}>2,4-\mathrm{D}$; malathion. IG50s values for the majority of the toxicants were on the lower end of the acute toxicity range. This acute range is based on toxicity from several invertebrates (crustaceans and insects) and fish (USEPA, 1986). However, IG50s were higher than the water quality range indicating that at this level of protection, $C$. inflata population growth should not be significantly affected.

Table 3 lists the median effective concentration (EC50) or the median lethal concentration (LC50) of several species of protozoa to the eight compounds 
Table 2. Sensitivity (espressed as inhibition of growth for 50\% of the population, IG50, no observed effect concentration, NOEC, and lowest observed effect concentration, LOEC) of $C$. inflata to eight compounds in $24 \mathrm{hr}$ tests. Values in parentheses are $95 \%$ confidence intervals. Tests were conducted in mimimal salts media. Acute toxicity range is based on water quality criteria (USEPA, 1986). All values in $\mathrm{mg} / \mathrm{L}$.

\begin{tabular}{|c|c|c|c|c|c|}
\hline Compound & IG50 & LOEC & NOEC & Acute Toxicity Range & Water Quality Criteria Range \\
\hline $\begin{array}{l}\text { Ammonia } \\
\text { (un-ionized) }\end{array}$ & $\begin{array}{c}0.019 \\
(0.013-0.029)\end{array}$ & 0.0094 & -- & $\begin{array}{c}0.083-23 \text { (uncorrected } \\
\text { values) }\end{array}$ & $0.0019-0.051$ \\
\hline $\mathrm{Cd}$ & $\begin{array}{c}0.020 \\
(0.01-0.03)\end{array}$ & 0.01 & 0.0072 & $0.001-28$ & $0.0011-0.0039$ \\
\hline $\mathrm{Cu}$ & $\begin{array}{c}0.059 \\
(0.02-0.14)\end{array}$ & 0.06 & - & $0.017-10$ & $0.012-0.018$ \\
\hline $2,4-\mathrm{D}$ & $>230$ & - & 230 & $37-130$ & 0.1 \\
\hline Malathion & $>99$ & - & 99 & $0.00076-0.29$ & 0.0001 \\
\hline PCP & $\begin{array}{c}0.27 \\
(0.18-0.39)\end{array}$ & 0.28 & 0.14 & $0.0044-44$ & $0.013-0.020$ \\
\hline SDS & $\begin{array}{c}52 \\
(38-74)\end{array}$ & 33 & 20 & 15 & - \\
\hline $\mathrm{Zn}$ & $\begin{array}{c}0.13 \\
(0.08-0.21)\end{array}$ & - & - & $0.051-89$ & $0.11-0.12$ \\
\hline
\end{tabular}


Table 3. EC50/LC50 values of several species of protozoa (in $\mathrm{mg} / \mathrm{L}$ ). Ranges indicate that EC50/LC50 values were found more than once for the same test species.

\begin{tabular}{|c|c|c|c|c|c|c|c|c|}
\hline Test Organism & Ammonia & $\mathrm{Cd}$ & $\mathrm{Cu}$ & $2,4-D$ & Malathion & PCP & SDS & $\mathrm{Zn}$ \\
\hline $\begin{array}{l}\text { Colpidium } \\
\text { campylum }^{\mathrm{a}}\end{array}$ & -- & $0.05-0.171$ & 0.17 & $>10$ & $>10$ & $0.6-1.60$ & -- & 0.80 \\
\hline Colpoda cucullus ${ }^{\mathrm{b}}$ & - & 0.22 & 0.97 & - & -- & - & - & 1.37 \\
\hline Colpoda inflata $^{\mathrm{c}}$ & 0.019 & 0.02 & 0.059 & $>230$ & $>99$ & 0.27 & 53 & 0.13 \\
\hline Colpoda stenii ${ }^{\mathrm{d}}$ & - & 0.22 & 0.25 & - & - & - & - & 0.85 \\
\hline $\begin{array}{l}\text { Entosiphon } \\
\text { sulcatum }^{\mathrm{e}}\end{array}$ & - & 0.011 & 0.11 & - & - & - & 40 & - \\
\hline $\begin{array}{l}\text { Spirostomum } \\
\text { ambiguum }^{\mathrm{f}}\end{array}$ & - & $0.078-5.27$ & $0.004-0.006$ & -- & - & - & $1.63-12.1$ & - \\
\hline $\begin{array}{l}\text { Tetrahymena } \\
\text { pyriformis }^{\mathrm{g}}\end{array}$ & - & $0.038-0.112$ & $0.045-0.132$ & $>500$ & -- & $0.15-0.30$ & - & - \\
\hline
\end{tabular}

a: Le Du et. al, 1993; Dive et al., 1989; Dive et. al., 1980 (24 hr EC50, organic medium); b: Janssen et. al, 1995 (7 d EC50, organic medium); c: This study (24 hr IG50/EC50, inorganic medium); d: Forge et. al, 1993 (24 hr EC50, inorganic medium);

e: Bringmann and Kuhn, 1980 (72 hr EC50, hard water); f: Nalecz-Jawecki et al., 1993 (24 hr LC50, hard and soft water);

g: Roberts and Berk, 1993 (1hr, 5hr EC50, 24 hr LC50, organic medium); Yoshioka et al., 1985 (24 hr EC50, organic medium) 
studied in this research. Many of these experiments were conducted under substantially different test conditions, so direct comparison would be unreasonable. However, it is a good representative account of current protozoan toxicology. Cadmium and copper were the most studied with these species, followed by zinc. A few studies have also been performed with PCP, SDS, and 2,4-D, but, only one other investigation involved malathion. No documentation on toxicity of ammonia to protozoa was found.

According to the table, considerable differences in responses to compounds exist among and within species. Variation among species could be due to differences in test conditions, but it is interesting to note that there are some similarities. Values for copper were never higher than $0.97 \mathrm{mg} / \mathrm{L}$. For cadmium and zinc, only one value was higher than $1.0 \mathrm{mg} / \mathrm{L}$ and that was most likely an artifact of to methodology. The 5.27 $\mathrm{mg} / \mathrm{L} \mathrm{LC50}$ for cadmium on $S$. ambiguum was tested in hard water and the EC50 of zinc on $C$. cucculus $(1.37 \mathrm{mg} / \mathrm{L})$ was calculated over a seven day period. All tests with 2,4-D and malathion found no effect. All tests conducted with PCP revealed toxicity values below $1.6 \mathrm{mg} / \mathrm{L}$. The PCP EC50 values $(0.6 \mathrm{mg} / \mathrm{L}$ and $1.6 \mathrm{mg} / \mathrm{L})$ with $C$. campylum were determined with the same methods. SDS values ranged from 1.63 $\mathrm{mg} / \mathrm{L}$ to $52.24 \mathrm{mg} / \mathrm{L}$. Large differences to tested compounds also occurred within each species, even when the same test method was used. Therefore, like $C$. inflata, other protozoa seem to be sensitive to some compounds and more tolerant of others.

A comparison of several rapid-screening toxicity tests with standard toxicity tests is listed in Table 4. There is significant variation in responses among test 
Table 4. LC50/EC50 endpoints (in mg/L) of several rapid and standard toxicity tests currently being utilized (from Toussaint et. al., 1995)

\begin{tabular}{|c|c|c|c|c|c|c|c|c|c|c|c|}
\hline \multicolumn{7}{|c|}{ Rapid ToxicityTests } & \multicolumn{5}{|c|}{ Standard Toxicity Tests } \\
\hline Compound & C.inflata & Rotifer & Microtox@ & $\begin{array}{l}\text { Brine } \\
\text { Shrimp }\end{array}$ & Polytox ${ }^{\circledR}$ & Lettuce & D. magna & C. dubia & $\begin{array}{l}S . \\
\text { capricornutum }\end{array}$ & $\begin{array}{l}P . \\
\text { promelas }\end{array}$ & $\begin{array}{l}\text { M. } \\
\text { bahia }\end{array}$ \\
\hline Ammonia & 0.019 & 4.6 & 1.75 & 14.6 & $>20$ & 0.03 & 1.2 & 2.18 & $\cdots$ & 1.59 & 1.4 \\
\hline Cadmium & 0.020 & 1.3 & 1.2 & 160 & 46 & 0.06 & 0.065 & 0.11 & 0.04 & 2.02 & 0.03 \\
\hline Copper & 0.059 & 0.026 & 1.3 & 4.9 & 38 & 0.62 & 0.052 & 0.027 & 0.04 & 0.48 & 0.16 \\
\hline 2,4-D & $>230$ & 117 & 101 & $>151$ & $>302$ & $<0.5$ & 25 & 236 & 95.8 & 227 & -- \\
\hline Malathion & $>99$ & 33.7 & 10 & $>25$ & $>50$ & $>53$ & 0.001 & - & $\cdots$ & 11.8 & 4.2 \\
\hline PCP & 0.27 & 1.2 & 1.02 & 0.51 & 90 & 0.59 & 0.37 & 0.28 & 0.34 & 0.23 & -- \\
\hline SDS & 53 & 1.4 & 1.8 & 19.1 & 470 & 5.34 & 9.6 & 48.4 & 3.75 & 8.0 & 6.6 \\
\hline Zinc & 0.13 & 1.3 & 12 & $>20$ & 31 & 2.44 & 0.56 & 0.076 & 0.06 & 2.65 & 0.499 \\
\hline
\end{tabular}


organisms and it should be noted that no species was the most sensitive to all compounds. When compared with all tests, $C$. inflata was the most sensitive to cadmium and un-ionized ammonia. For copper, the rotifer, Branchionus calyciflorus, and Ceriodaphnia dubia were the most sensitive followed by Daphnia magna and Selenastrum capricornutum. $C$. inflata displayed sensitivities close to the standard tests of D. magna and S. capricornutum. The brine shrimp and Polytox $\AA_{\text {(a bacteria }}$ mixture) were similar to $C$. inflata in the tolerance to 2,4-D and malathion. The lettuce root growth test and D. magna were by far the most sensitive to 2,4-D and malathion, respectively. $C$. inflata ranked among the most sensitive organisms for PCP (the fathead minnow, Pimephales promelas, $C$. dubia and D. magna) and for zinc (C. dubia and $S$. capricornutum). The IG50 for SDS is comparable to the LC50 for C. dubia, which is the second most tolerant to this compound.

A ranking of mean sensitivity to these eight compounds by each toxicity was calculated and is shown in Figure 2. The most sensitive test for each compound was scored as a one, and the number increased as tolerance increased (most tolerant scored as 11). Values which were not found or were not determined (greater than EC50/LC50s) were not ranked. For each test organism, the ranks were summed and averaged to estimate the average sensitivity. The order of sensitivity of test organisms was: S. capricornutum $>$ M. bahia; C. inflata $>$ D. magna $>$ Lettuce $>$ C. dubia $>$ B. calyciflorus $>$ P. promelas $>$ Microtox ${ }^{\circledR}>$ brine shrimp $>$ Polytox ${ }^{\circledR}$. C. . inflata appears to be one of the most sensitive test organisms on this list. 


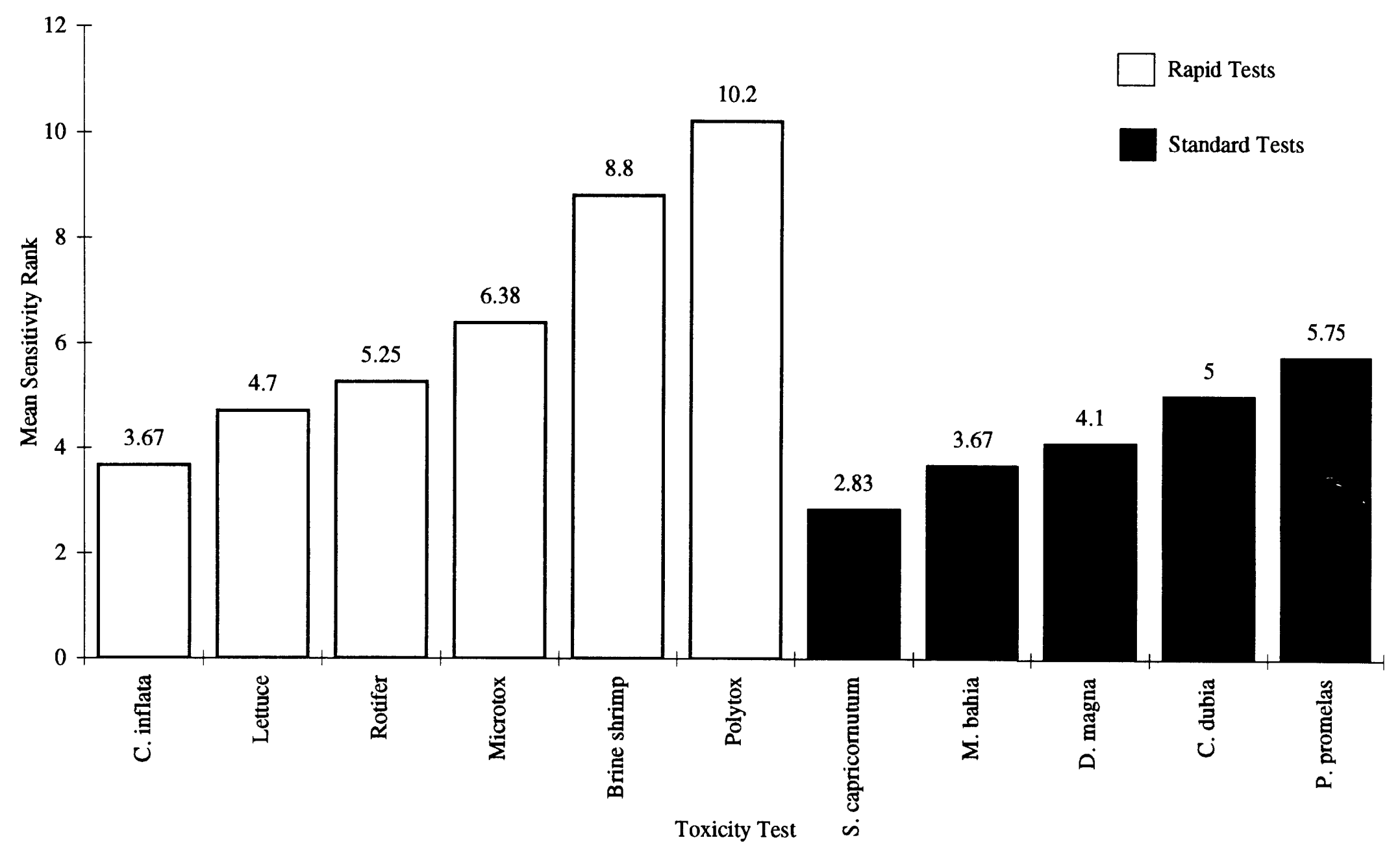

Figure 2. Average relative sensitivity rank of rapid-screening and standard acute toxicity tests. Ranks were determined by LC50/EC50 values in Table 4. The most sensitive test for each compound was scored as a 1; ranks increased as tolerance increased. 
Previous experiments with metal compounds, conducted by several undergraduates, yielded similar IG50s to those in this study. Test methods were slightly different, but comparable in the use of $10 \%$ Sonneborn's medium (J.R. Pratt, unpublished research). Also, preliminary tests conducted for this graduate research showed low variability among tests conducted on separate days. These data are not included because they occurred before a standard method was determined. Given this information, it can be concluded that this test gives repeatable results when conducted by different technicians as well as with different cultures, stocks, and test media.

\section{Bioavailability}

The toxicity of several compounds appear to be altered by the type of medium used (Table 5 ).

Metals. Cadmium and copper displayed the largest effect between the organic and inorganic media. This difference in sensitivity is most apparent in the doseresponse curves (Figures 3 and 4), which show an obvious difference between all treatments in the organic and inorganic media. For both cadmium and copper, the IG50 value for $C$. inflata dosed in $10 \%$ Sonneborn's were significantly different than those dosed in 5\% Sonneborn's and minimal salts media. Minimal salts media resulted in the lowest IG50 values and organisms exposed in 5\% Sonneborn's displayed IG50 levels between minimal salts and $10 \%$ Sonneborn's. 
The effects of the organic media on zinc toxicity, were not as apparent. For zinc, ciliates tested in 5\% Sonneborn's had the lowest IG50, followed by minimal salts and $10 \%$ Sonneborn's media. The IG50 values of these three media were not statistically different. The dose-response of zinc (Figure 5) shows an overlap among different media.

Table 5. Effects of six compounds on C. inflata growth in organic (Sonneborn's) and inorganic (minimal salts) media . Values are IG50s in $\mathrm{mg} / \mathrm{L}$. Numbers in parentheses are $95 \%$ confidence intervals. A star $\left(^{*}\right)$ indicates a significant difference in response among media.

\begin{tabular}{clll}
\hline Compound & Minimal Salts & $10 \%$ Sonneborn's & 5\% Sonneborn's \\
\hline Metals & & & \\
$\mathrm{Cd}$ & 0.020 & $0.083^{*}$ & 0.023 \\
& $(0.01-0.032)$ & $(0.05-0.131)$ & $(0.02-0.032)$ \\
$\mathrm{Cu}$ & 0.059 & $0.58^{*}$ & 0.16 \\
& $(0.02-0.14)$ & $(1.3-2.3)$ & $(0.12-0.20)$ \\
$\mathrm{Zn}$ & 0.13 & 0.17 & 0.080 \\
& $(0.08-0.21)$ & $(0.10-0.27)$ & -- \\
Non-metals & & & - \\
Ammonia & 0.019 & 0.017 & - \\
& $(0.013-0.029)$ & $(0.018-0.027)$ & \\
PCP & 0.27 & $>1.9 *$ & - \\
& $(0.18-0.40)$ & & \\
SDS & 52 & 71 & $(49-102)$ \\
& $(38-74)$ & &
\end{tabular}


Many researchers have demonstrated the occurrence of chelation of metals in organic media, implying that a significant difference in sensitivity could occur due to the bioavailability of the compound (e.g. Dive et al, 1982; Dallinger and Rainbow, 1993). This is an important factor in toxicity testing, and test designs should incorporate the possibility of chelation to test compounds.

Metals have been documented to display the highest change in bioavailabilty in the presence of organic material (Depledge et al., 1994). The tests conducted in this research show that $C$. inflata was able to respond accordingly to a change in toxicity due to bioavailabilty. Toxicity of cadmium and copper were found to be significantly different between the 10\% Sonneborn's and 5\% Sonneborn's and minimal salts. The DOC concentration was measured to be $40 \mathrm{mg} / \mathrm{L}$ in $10 \%$ Sonneborn's medium and assumed to be close to zero in the minimal salts medium. IG50s were related to the amount of DOC in test media (i.e., high IG50, high DOC concentration). Many studies have demonstrated the decreasing bioavailability of certain substances as the concentration of DOC increases (Dallinger and Rainbow, 1993; Depledge et al. 1994). Almost all of these studies have been conducted on multicellular organisms such as insects, crustaceans, and fish. Research on bioavailabilty measured by protozoa is scarce. A bioassay investigating the complexation of cadmium with humic substances found that the growth of the ciliate, C. campylum, in the presence of $\mathrm{Cd}$ responded to changes in humic concentrations (Dive et al., 1982). In comparison, the IG50s of 


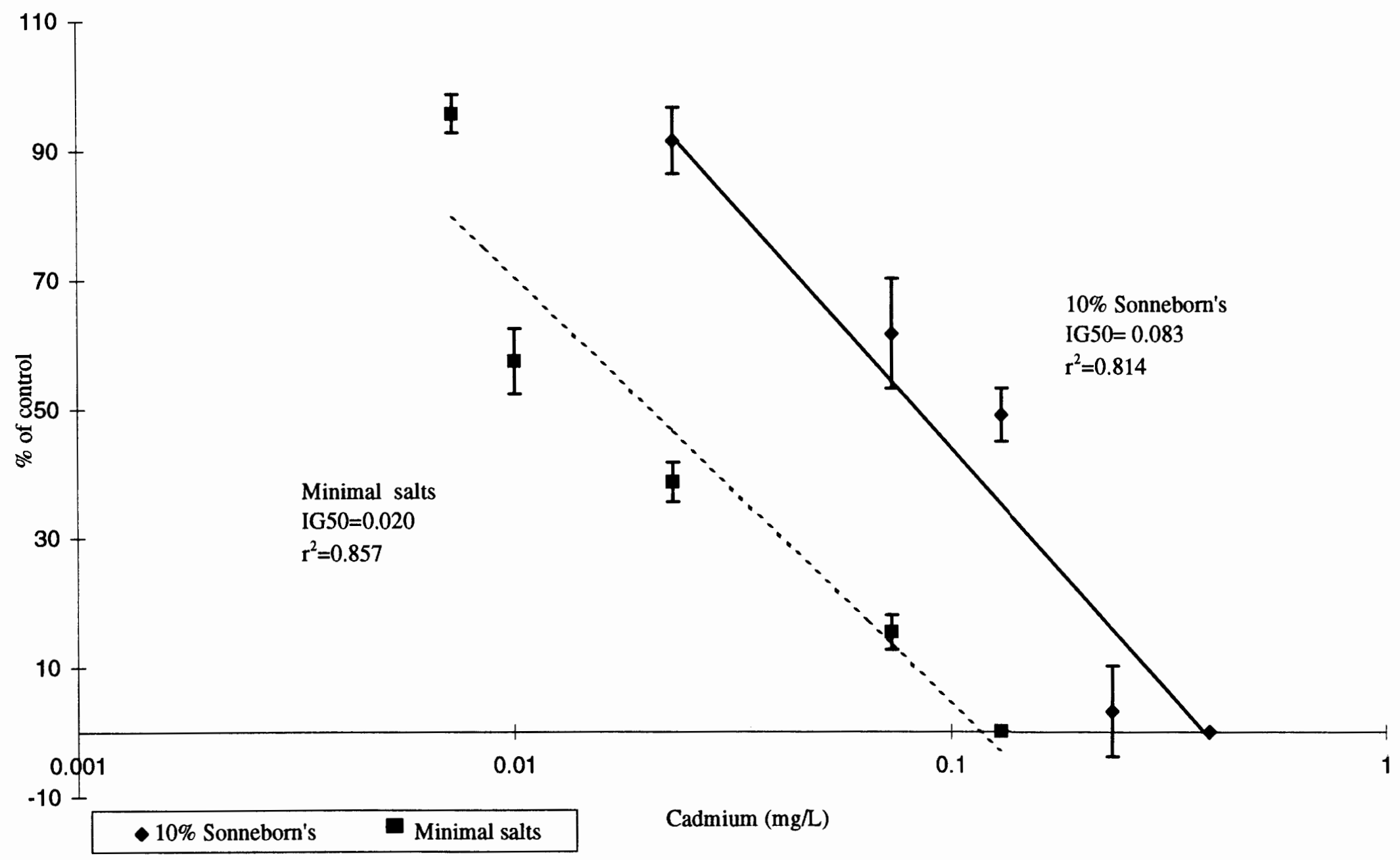

Figure 3. Dose-response curve illustrating the effects of cadmium on growth of $C$. inflata tested in organic and inorganic media. Solid line represents $10 \%$ Sonneborn's medium, dashed line is response in minimal salts medium. 


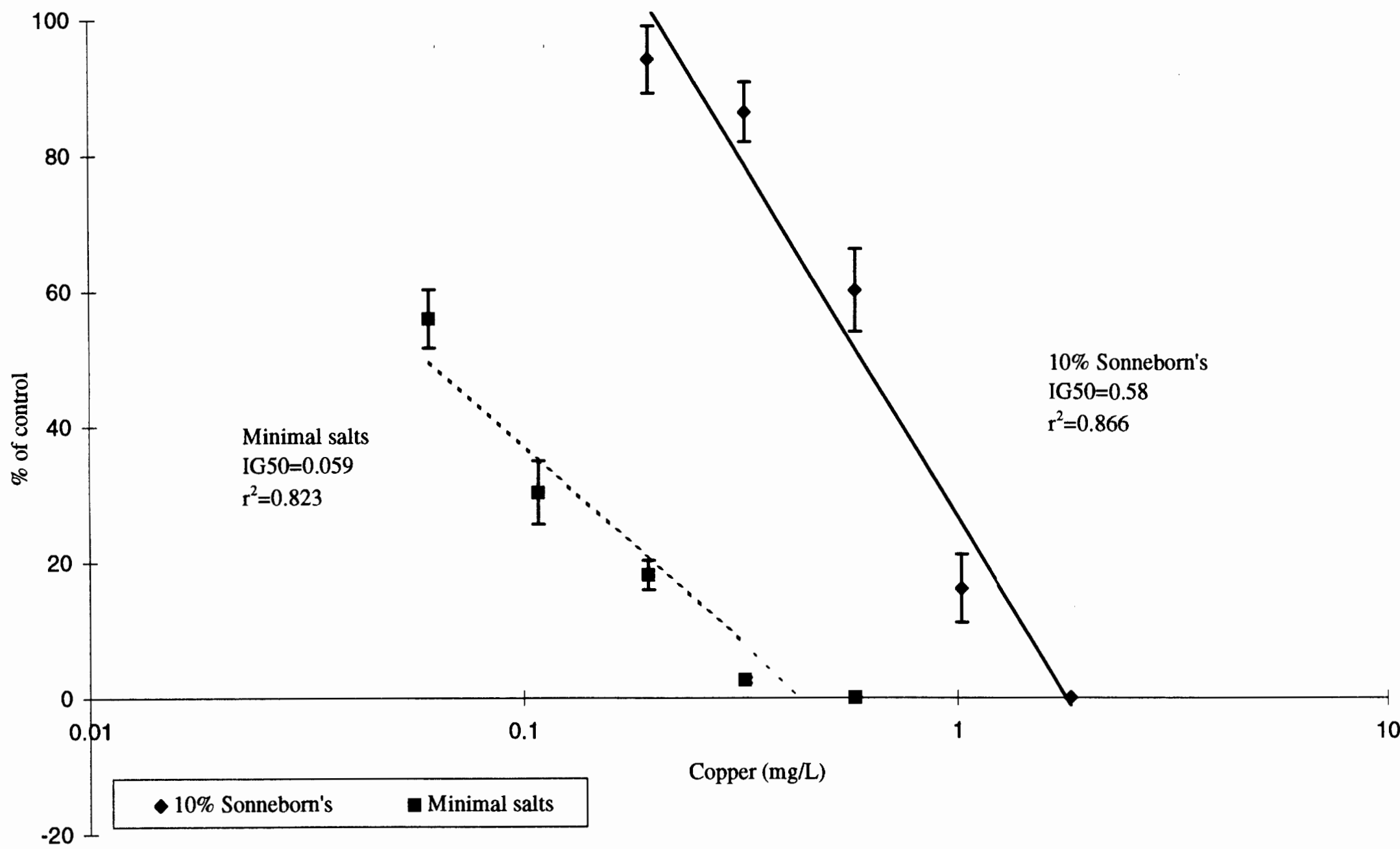

Figure 4. Dose-response illustrating the effects of copper on the growth of $C$. inflata tested in organic and inorganic media. Solid line represernts $10 \%$ Sonneborn's medium, dashed line is response in minimal salts medium. 


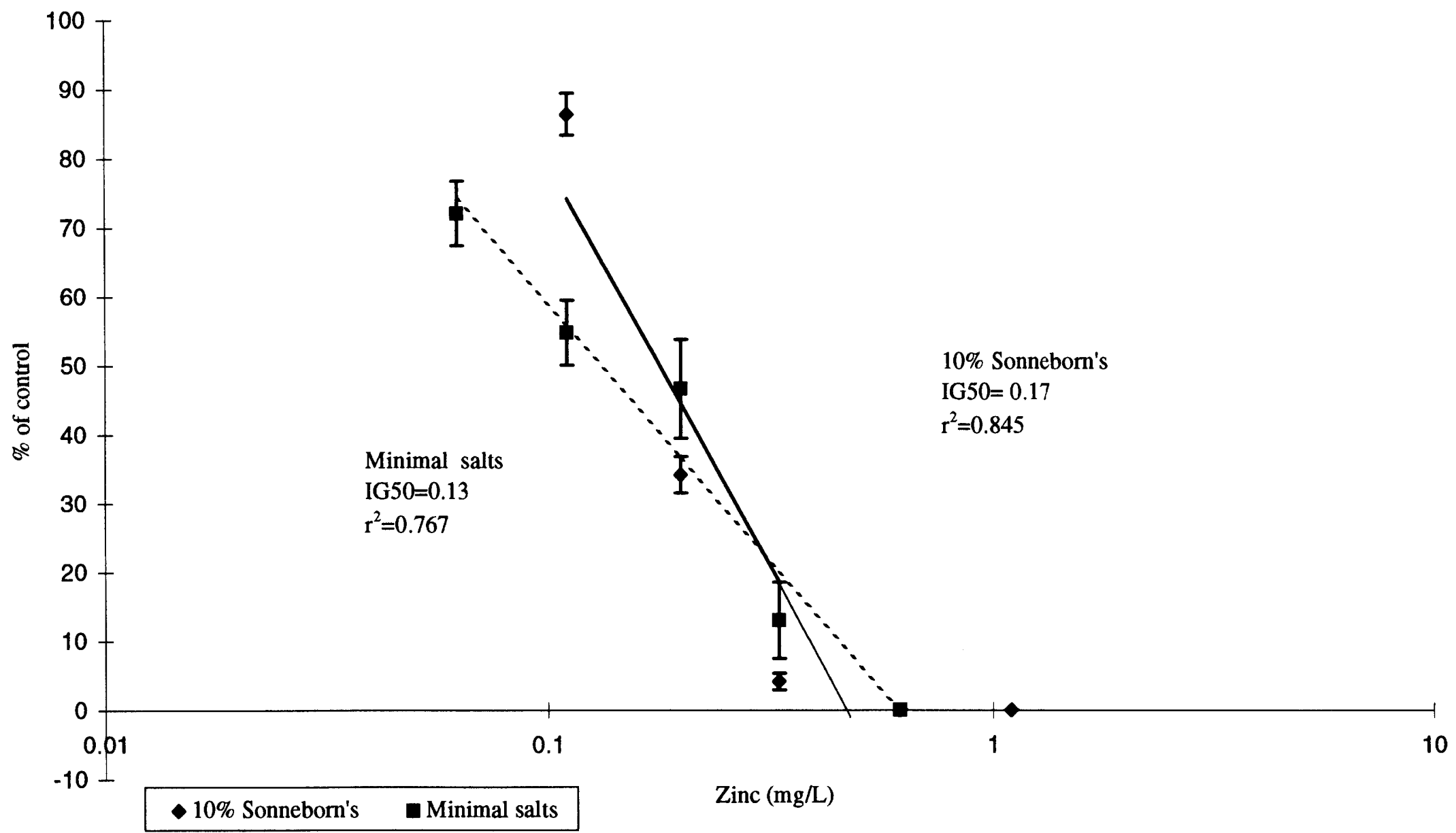

Figure 5. Dose-response curve illustrating the effects of zinc on growth of $C$. inflata tested in organic and inorganic media. Soild line represents $10 \%$ Sonneborn's medium, dashed line is response in minimal salts medium. 
cadmium and copper, obtained with this study of $C$. inflata, showed a significant difference between the organic and inorganic media. Thus, much like other bioavailability studies, the rapid-screening test with $C$. inflata is sensitive enough to distinguish complexation of metals with DOC.

Non-metals. Influences of different medium were also apparent in three nonmetal compounds. The largest difference in response appeared between the ciliates in the two media dosed with PCP. In the minimal salts media, the IG50 was $0.27 \mathrm{mg} / \mathrm{L}$ and in the organic media, ciliate growth was not inhibited at the highest possible dose $(1.9 \mathrm{mg} / \mathrm{L})$. In the SDS test, the minimal salts IG50 $(52 \mathrm{mg} / \mathrm{L})$ was lower than the IG50 from the $10 \%$ Sonneborn's media $(71 \mathrm{mg} / \mathrm{L})$, but not significantly different. However, the dose-response curve (Figure 6) showed the two responses overlapping in several places (but not at $50 \%$ of the control). Ammonia results were opposite of trends shown in other compounds in which the inorganic medium lead to higher toxicity than organic medium. In these tests, ciliates in minimal salts were less sensitive than those in the $10 \%$ Sonneborn's media (IG50s were $0.019 \mathrm{mg} / \mathrm{L}$ and $0.017 \mathrm{mg} / \mathrm{L}$, respectively). The dose-response (Figure 7) showed a slight difference between responses at the higher treatments, although the IG50s were not significant.

There is limited information on the concentration response of aquatic humic substances with regards to organic pollutants. However, several studies have investigated the possibility of PCP binding to natural dissolved organic matter 


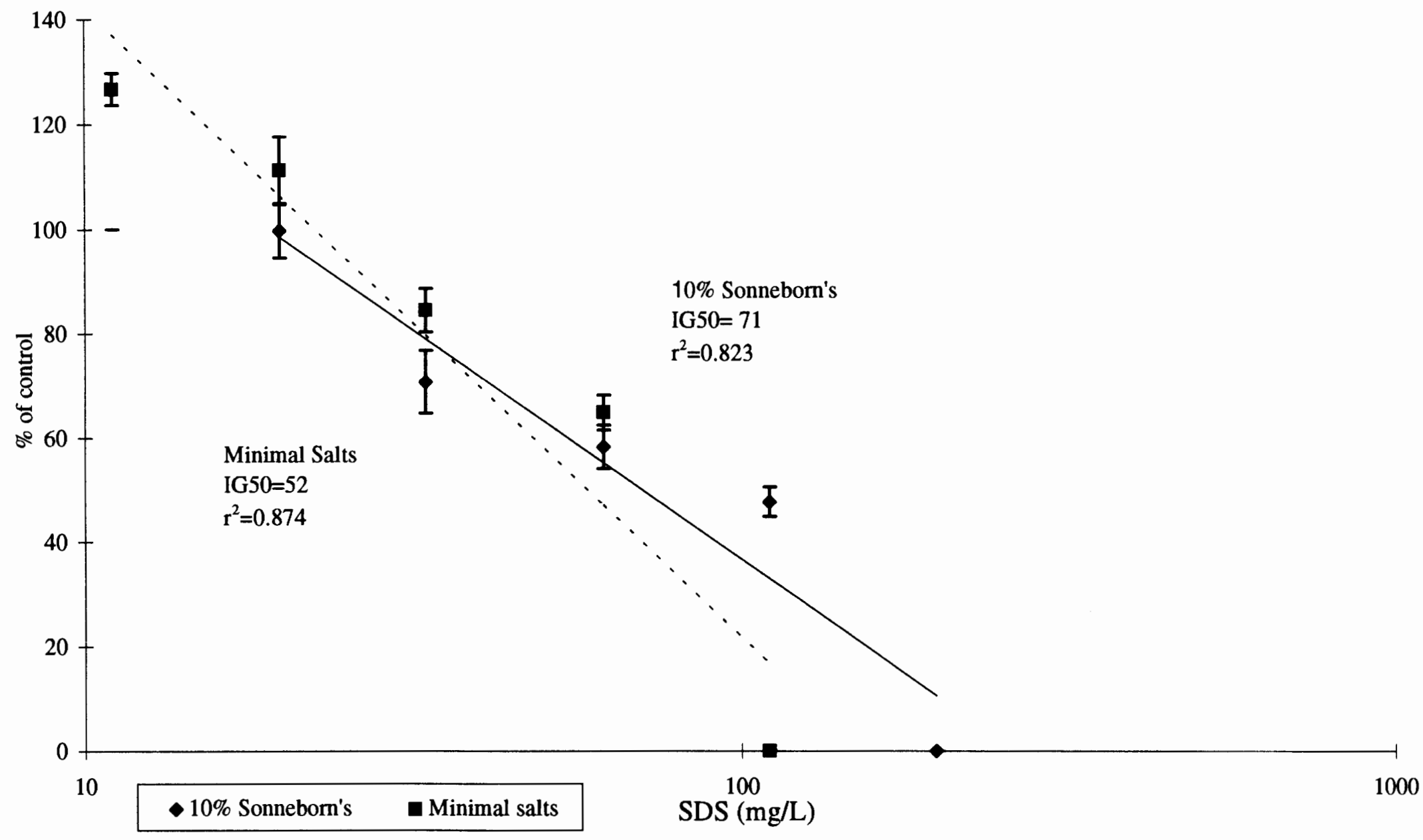

Figure 6 . Dose-response illustrating the growth of $C$. inflata to SDS in organic and inorganic media. Solid line represents $10 \%$ Sonneborn's medium, dashed line is response in minimal salts medium. 


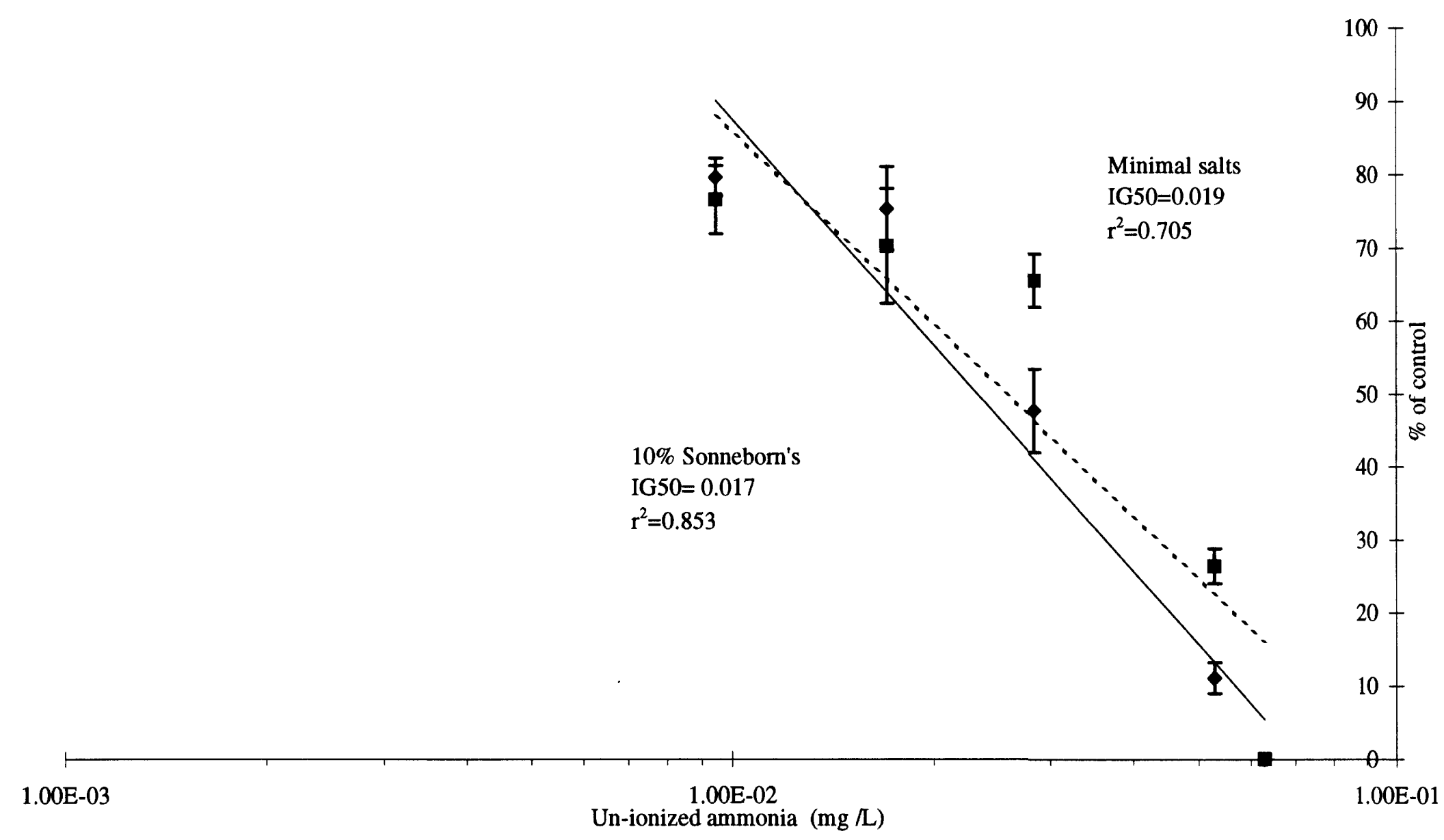

Figure 7. Dose-response illustrating effects of calculated un-ionized ammonia on growth of C. inflata tested in organic and inorganic media. Solid line represent $10 \%$ Sonneborn's medium, dashed line is reponse in mimimal salts medium. 
(NDOM). Kukkonen and Oikari (1987) observed that accumulation of labeled PCP by D. magna was not affected by humic water (DOC $=23.5 \mathrm{mg} / \mathrm{L}$ ), even after a 10 hour period. Lee et al. (1994) found that the toxicity of PCP to D. magna and the zebrafish, Brachydanio rerio, were not altered in the presence of dissolved humic materials (where total organic carbon concentrations were $0-50 \mathrm{mg} / \mathrm{L}$ ). However, research has shown that PCP does bind to sediments and suspended particles in water (Murray et al., 1981). An important factor of PCP absorption to NDOM (at $15 \mathrm{mg} / \mathrm{L}$ as DOC) is $\mathrm{pH}$ and that absorption also depends on the concentration of PCP (Lafrance et al., 1994).

Since many studies have shown that the concentration of humic material/ NDOM does not seem to affect bioavailibity, there may be some other reason for the difference observed in this research. PCP is known to be highly photodegradable and biodegradable in the soil with a half-life ranging from 15 to 48 days (in anaerobic and aerobic laboratory conditions, respectively). In water, PCP has a half-life ranging from hours to days (Verschueren, 1983). However, stocks of PCP were made in sterilized media the day prior to the testing and refrigerated in amber glass bottles (thus decreasing the possibility of photodegredation). It is possible that the PCP stock made with $10 \%$ Sonneborn's was contaminated. Also, the cultures of $C$. inflata certainly contained some bacteria not intentionally added. However, bacteria were also added to the tests with the minimal salts medium so it is unlikely that microbial degradation can be completely responsible for the differences in toxicity. 
Slight differences in sensitivity between media, if any, appeared with SDS and ammonia. The growth curve of SDS crosses in several places suggesting that there really was no effect between media. For ammonia, however, there seemed to be an increasingly large difference in sensitivities as the concentration of ammonia increased. Ammonia can be absorbed on soil and sediment particles (NRC, 1979). However, the results presented here suggest that bioavailabilty due to complexation with DOC did not occur in this research. Because $C$. inflata appears to be more sensitive in the $10 \%$ Sonneborn's than the minimal salts media, it cannot be binding to the high amount of DOC found in $10 \%$ Sonneborn's. It is well documented that $\mathrm{pH}$ and temperature are crucial factors in determination of ammonia toxicity and ammonia is generally more toxic at relatively high, rather than relatively low, $\mathrm{pH}$ (USEPA, 1986). This may be due to the ability of ammonia to cross membranes more readily and cause toxicity (NRC, 1979). Because both these tests were incubated at a constant temperature of $25^{\circ} \mathrm{C}$, it is unlikely that temperature played a role in the small difference in sensitivity between these two media. The $\mathrm{pH}$ of $10 \%$ Sonneborn's was 6.8 and the $\mathrm{pH}$ of minimal salts was 5.4, so it is possible that $\mathrm{pH}$ may cause this small contrast. While these differences should not be considered significant in this research, future research should investigate this possibility. 


\section{Pesticides}

Three pesticides were tested: the herbicide $2,4-\mathrm{D}$, the insecticide malathion, and the fungicide/multipurpose pesticide PCP (Table 2). While PCP did not affect $C$. inflata in $10 \%$ Sonneborn's ( IG50 >1.9 mg/L), in minimal salts media the IG50 was $0.27 \mathrm{mg} / \mathrm{L}$. C. inflata population growth was not significantly inhibited in either 2,4-D or malathion in either media at the highest concentrations tested $(230$ and $99 \mathrm{mg} / \mathrm{L}$, respectively).

Most protozoan pesticide studies have investigated the effects of pesticides on protozoa communities (e.g., change in community structure, respiration, biomass, etc.; see Foissner, 1994). Only a few studies have investigated direct effects on individual species, and even less investigation has been conducted on the pesticides used in this research. Dive et. al. (1980) investigated the effects of several pesticides on the ciliated protozoan, C. campylum. Their research found that even at a concentration of $10 \mathrm{ppm}$, many pesticides were not toxic to this species. Among the most toxic, however, was PCP at a minimal active dose (MAD) of $0.6 \mathrm{mg} / \mathrm{L}$ Both $2,4-\mathrm{D}$ and malathion were not toxic at the highest level tested $(10 \mathrm{mg} / \mathrm{L})$. Another study by Le Du et al (1993), also using C. campylum as the test species, found that PCP at a concentration of $1.60 \mathrm{mg} / \mathrm{L}$ inhibited the growth of $50 \%$ of the population. Also compared in this research was the effects of PCP on Tetrahymena pyriformis, a freshwater ciliated protozoan. With $T$. pyriformis, the EC50 of PCP was $0.30 \mathrm{mg} / \mathrm{L}$. T. pyriformis was also shown not to be affected by 2,4-D at a concentration of $500 \mathrm{mg} / \mathrm{L}$ (Roberts and Berk, 1993). 
An important aspect of understanding the toxicity of any compound is understanding its mode of toxic action. This often gives an indication why a pesticide may not be toxic to a particular species.

PCP, a chlorinated hydrocarbon, is a multipurpose pesticide that is currently being phased out of use. It was used mainly as a wood preservative and treatment against fungi and wood-boring insects, but has also been used an herbicide, molluscicide, algicide, and a disinfectant. The mechanism for toxicity is not well documented (Amdur et. al., 1991); however, it is generally accepted that PCP acts as an uncoupler of oxidative phosphorylation (Cockerham and Shane, 1994; De Bruin, 1976). Oxidative phosphorylation occurs in all living organisms to produce ATP using energy created from the redox reactions of the electron transport system (ETS). In mitochondria, uncouplers like PCP destroy the proton gradient, making the lipid membrane lose hydrogen ions. Electrons can still be passed down the ETS, but because there is no proton gradient, no ATP can be made. ATP is necessary for energy to drive cellular reactions, without the ability to produce ATP, the organism dies (Becker and Deamer, 1991).

Used as an herbicide for selective control of broadleaf plants, 2,4-D (a chlorophenoxy herbicide) stimulates plant growth by mimicking the effect of auxin, a natural growth hormone. As 2,4-D is translocated into all cells, cell proliferation and elongation becomes uncontrolled and disrupts normal plant growth. This leads to a reduction in water uptake, leaf expansion and increased chloroplast production, 
followed by a softening of the root cortex and overall necrosis (Amdur et. al. 1991). the presence of auxin has not been documented in protozoa. Because $C$. inflata does not contain chloroplasts or plant hormones it is unlikely that it would be toxic by this mode of action. Many other non-plant test organisms, such as C. dubia, P. promelas, or brine shrimp (see Table 4), also are not very sensitive to 2,4-D.

Malathion, an organphosphorus insecticide, is a neurotoxin. It works by inhibiting the enzyme cholinesterase which normally breaks down the neurotransmitter acetylcholine at the synapse. Malathion combines with the active site of cholinesterase, making it unable to work effectively. This results in an accumulation of acetylcholine at the nerve endings, allowing continual neural stimulation and ultimately leading to death of the organism (Becker and Deamer, 1991). Cholinesterase has not been documented in protozoa. $C$. inflata does not have a central nervous system (Meglitsh and Schram, 1991; Foissner, 1993), so malathion is unlikely to significantly affect $C$. inflata. Several metazoan tests species are sensitive to malathion, with arthropods such as D. magna, being the most sensitive (Table 4).

While 2,4-D and malathion did not negatively affect $C$. inflata growth, there is a possibility that these ciliates may accumulate these toxins. Toxins could become concentrated in organelles, such as digestive vacuoles, or in membranes (Dive et al., 1980; Cooley et al., 1972). While this may seem harmless, it could lead to bioaccumulation. A study on bacteria by Wolfaardt et al. (1994) showed that cell capsules and certain regions of the expolymer matrix can accumulate parent 
compounds as well as the secondary products. Products also accumulated in biofilms. When protozoa indiscriminately graze on these bacteria and related biofilms, protozoa are also ingesting the accumulated compounds. Several organic compounds, including PCP were found to have a high bioaccumulation potential to a green alga (Geyer et al., 1981). Research tracing bioaccumulation from protozoa to other animals is rare; however, there is also no strong evidence indicating that bioaccumulation does not occur.

In summary, while $C$. inflata did not display a significant difference in growth for 2,4-D and malathion in both media, and PCP did not affect growth in 10\% Sonneborn's, these data cannot be disregarded. Although not investigated in this study, bioaccumulation could possibly occur leading to an effect on other organisms in an ecosystem. C. inflata was sensitive to PCP in the inorganic medium, so this test should not be completely disregarded as a test for pesticides. 


\section{CONCLUSIONS}

Evaluation of this rapid-screening toxicity test using $C$. inflata, has yielded several conclusions. First, this test is sensitive enough to respond to a variety of compounds. Ranges of IG50s are comparable to other protozoan bioassays as well as other rapid-screening and standard tests. $C$. inflata was not the most sensitive to all compounds tests, however it was intolerant to many. In fact, when ranked with other tests, $C$. inflata was found to more sensitive than standardized tests using organisms such as D. magna, C. dubia, and $P$. promelas. $C$. inflata also ranked higher in sensitivity than many of the rapid-screening tests currently used (like Microtox $\circledast$, Polytox®, rotifer, and the brine shrimp).

This test is sensitive enough to respond to differences in toxicity due to bioavailability. Tested in both organic and inorganic media, $C$. inflata displayed a higher tolerance to compounds tested in the organic media. This was especially true for cadmium and copper. This test is sensitive enough to detect chelation of metals by DOC.

Lastly, as in other protozoa and several other organisms, there was no significant effect found for two of the three pesticides tested. This may be simply because the physiological characteristics of protozoan and the pesticides' modes of action do not overlap. Because $C$. inflata was affected by one pesticide, it would be unwise to overlook using protozoa bioassays for pesticide testing. 
C. inflata is an easily cultured protozoan that occurs world-wide. With this test, effects of compounds an be assessed quickly and inexpensively. It displays similar responses to other test organisms and results are repeatable. This test would be a worthy addition to use in a battery approach. 


\section{LITERATURE CITED}

Amdur, M.O., J. Doull, C.D. Klassen, eds. 1991. Toxicology: the basic science of poisons, 4th ed. Pergamon Press, Elmsford, NY, USA.

American Public Health Association, American Water Works Association (APHA) and Water Pollution. 1989. Standard methods for the examination of water and wastewater, 17th ed. American Public Health Association, Washington, D.C., USA.

Becker, W.M. and D.W. Deamer. 1991. The world of the cell, 2nd ed. The Benjamin/Cummings Publishing Company, Inc., Redwood, CA, USA.

Bowers, N.J. and J.R. Pratt. 1995. Estimation of genetic variation among soil isolates of Colpoda inflata (Stokes) (Protozoa: Ciliophora) using the polmerase chain reaction and restriction fragment length polymorphism analysis. Arch. Protistenkd. 145: 29-36.

Bringmann, G. and R. Kuhn. 1980. Comparison of the toxicity thresholds of water pollutants to the bacteria, algae, and protozoa in the cell multiplication inhibition test. Water Res. 14: 231-241.

Cairns, J. Jr. 1974. Protozoans (Protozoa). In Hart, C.W., Jr. and S.L.H. Fuller, eds. Pollution ecology of freshwater invertebrates. Academic Press, Inc., New York, NY, USA.

Cairns, J. Jr. 1986. The myth of the most sensitive species. BioScience. 36:670-672.

Caims, J. Jr. and J.R. Pratt. 1989. The scientific basis of bioassays. Hydrobiologia. 188/189: 5-20.

Cockerham, L.G. and B.S. Shane, eds. 1994. Basic environmental toxicology. CRC Press, Boca Raton, F.L., USA.

Cooley, N.R., J.M. Keltner and J. Forester. 1972. The polychorinated biphenyls, Arochlors 1248 and 1260: Effect on accumulation by Tetrahymena pyriformis. J. Protozool. 20: 443-445.

Dallinger, R. and P.S. Rainbow, eds. 1993. Ecotoxicology of metals in invertebrates. Lewis Publishers, Boca Raton, F.L., USA. 
Depledge, M.H., J.M. Weeks and P. Bjerregaard. 1994. Heavy metals. In P. Calaw, ed. Handbook of ecotoxicology, vol 2. Blackwell Science Publishers, Oxford, UK. pp 79-105.

Dive, D., H. Leclerc and G. Persoone. 1980. Pesticide toxicity on the ciliate protozoan Colpidium campylum: possible consequences of the effect of pesticides in the aquatic environments. Ecotox. Environ. Saf. 4: 129-133.

Dive, D., N. Pommery, M. Lalande and F. Erb. 1982. Cadmium complexation by humic substances: chemical and ecotoxicological study with ciliate protozoan Colpidium campylum. Can. Tech. Rep. Fish. Aquat. Sci. 1163: 9-21.

Dive, D., S. Robert, E. Angrand, C. Bel, H. Bonnemain, L. Brun, Y. Demargue, A. Le $\mathrm{Du}, \mathrm{R}$. El Bouhouti, M.N. Fourmaux, L. Guery, O. Hanssens and M. Murat. 1989. A bioassay using the measurement of growth inhibition of a ciliate protozoan: Colpidium campylum Stokes. Hydrobiologia 188/189: 181-188.

Dunnett, C.W. 1955. A multiple comparison procedure for comparing several treatments with a control. J. of Amer. Statisical Assoc. 50: 1096.

Elnabarawy, M.T., R.R. Robideau and S.A. Beach. 1988. Comparison of three rapid toxicity test procedures: Microtox $\circledast$, Polytox $\circledast$ and activated sludge respiration. Toxicity Assess. 3: 361-370.

Fenchel, T. 1988. The ecology of the protozoa: The biology of free-living phagotrophic protists. Science Tech. Publishers, Madison, WI, USA.

Foissner, W. 1993. Colpodea (Ciliophora). Gustav Fisher Verlag. Stuttgart, Jena, New York.

Foissner, W. 1994. Soil protozoa as bioindicators in ecosystems under human influence. In Darbyshire, J.F, ed. Soil Protozoa. CAB International, Wallingford, UK, pp 147-193.

Foissner, W. and H. Berger. 1996. A user-friendly guide to the ciliates (Protozoa, Ciliophora) commonly used by hydrobiologist as bioindicators in rivers, lakes and waste water, with notes on their ecology. Freshwater Biol. 35: 375-482.

Forge, T.A., M.L. Berrow, J.L. Darbyshire, A. Warren. 1993. Protozoan bioassays of soil amended with sewage sludge and heavy metals using the common soil ciliate Colpoda steini. Biol Fertil. Soils 16:282-286. 
Geyer, H., R. Viswanathan, D. Freitag and F. Korte. 1981. Relationship between water soulubility of organic chemicals and their bioaccumulation by the alga Chlorella. Chemosphere. 10: 1307-1313.

Gray, J.S. and R.J. Ventilla. 1973. Growth rates of sediment-living marine protozoan as a toxicity indicator for heavy metals. Ambio 2: 118-121.

Janssen, C.R. and G. Persoone. 1993. Rapid toxicity screening tests for aquatic biota. 1. Methodology and experiments with Daphnia magna. Environ. Toxicol. Chem. 12: 711-717.

Janssen, M.P.M., C. Oosterhoff, G. J. S. M. Heijmans and H. Van der Voet. 1995. The toxicity of metal salts and the population growth of the ciliate Colpoda cucculus. Bull. Environ. Contam.Toxicol. 54: 597-605.

Jenne, E.A. and J.M. Zachara. 1987. Factors influencing the sorption of metals. Dickson, K.L., A.W. Maki, W.A. Brung, eds. 1987. Fate and effects of sediment-bound chemicals in aquatic systems. Pergamon Press, New York, NY, pp. 83-198.

Kimball, K..D. and S.A. Levin. 1985. Limitations of laboratory bioassays: the need for ecosystem level testing. BioScience. 35: 165-171.

Kukkonen, J. and A. Oikari. 1987. Effects of aquatic humus on accumulation and the acute toxicity of some organic micropollutants. Sci. Total Environ. 62: 399402.

Lafrance, P., L. Marineau, L. Perreault and J. P., Villeneuve. 1994. Effect of natural dissolved organic matter found in groundwater on soil adsorption and transport Environ. Sci. Technol. 28: 2314-2320.

Landis, W.G. and M.H. Yu. 1995. Introduction to environmental toxicology: Impacts of chemicals upon ecological systems. CRC Press, Inc., Boca Raton, F.L., USA.

Le Du, A., D. Dive, M. Guerbet and J.M. Jouany. 1993. The protozoan biotest Colpidium campylum, a tool for toxicity detection and toxic interaction modeling. Sci. Total Environ. Supplement 1993: 809-815.

Lee, S.K., D. Freitag, C. Steinberg, A. Kettrup and Y. H. Kim. 1993. Effects of dissolved humic materials on acute toxicity of some organic chemicals to aquatic organisms. Wat. Res. 27: 199-204. 
Loussier, J.D. and S.S. Bamforth. 1990. Soil Protozoa. In Dindal, D.L., ed. Soil biology guide. John Wiley and Sons, Inc. NY, USA.

Maugh, T. H., III. 1983. How many chemicals are there? Science. 220:293.

Meglitsch, P.A. and F.R. Schram. 1991. Invertebrate zoology, 3rd ed. Oxford University Press, New York, NY, USA.

Murray, H.E., L. E. Ray and C. S. Giam. 1981. Analysis of marine sediment, water and biota for selected organic pollutants. Chemosphere. 10:1327-1334.

Nalecz-Jawecki, G., K. Demkowicz-Dobrzanski and J. Sawicki. 1993. Protozoan Spirostomum ambiguum as a highly sensitive bioindicator for rapid and easy determination of water quality. Sci. Total Environ. Supplement 1993: 12271234.

National Research Council (NRC). 1979. Ammonia. University Park Press, Baltimore, MD, USA.

Pauli, W., S. Berger, L. Jaskulka and S. Schmitz. 1993. A case for the inclusion of a protozoan test in aquatic toxicology assessment using Tetrahymena. Sci. Total Environ. Supplement 1993: 779-786.

Perdue, E.M. and N.L. Wolfe. 1982. Modification of pollutant hydrolysis kinetics in the presence of humic substances. Env. Sci. Tech. 16: 847-852.

Prescott, D.M. and T.W. James. 1955. Culturing of Amoeba proteus on Tetrahymena. Exp. Cell Res. 8:256-258.

Pressley, T.A. and J.E. Longbottom. 1982a. The determination of organophosphorous pesticides in industrial and municipal wastewater: method 614. Environmental Monitoring and Support Laboratory, Office of Research and Development, U.S. Environmental Protection Agency.

Pressley, T.A. and J.E. Longbottom. 1982b. The determination of chlorinated herbicides in industrial and municipal wastewater: method 615. Environmental Monitoring and Support Laboratory, Office of Research and Development, U.S. Environmental Protection Agency.

Roberts, R.O. and S. G. Berk. 1993. Effect of copper, herbicides, and a mixed effluent on chemoattraction of Tetrahymena pyriformis. Environ. Tox. Wat. Qual. Int. 8: 73-85. 
Rogerson, A. and J. Berger. 1981. Effect of crude oil and petroleum-degrading microorganisms on the growth of freshwater and soil Protozoa. J. Gen. Microbiol. 124: 53-59.

Ruthven, J.A. and J. Cairns, Jr. 1973. Response of fresh-water protozoan artificial communities to metals. J. Protozool. 20: 127-135.

Schaeffer, D.J. 1994. Detection-bioassay. In Cockerham, L.G. and B.S. Shane, eds. 1994. Basic environmental toxicology. CRC Press, Boca Raton, F.L., USA.

Schreiber, B. and N. Brink. 1989. Pesticide toxicity using protozoans as test organisms. Biol. Fertil. Soils 7:289-296.

Snell, T.W. and G. Persoone. 1989. Acute toxicity bioassays using rotifers: II a freshwater test with Branchionus rubens. Aquat. Toxicol. 14: 81-89.

Sokal, R.R. and F.J. Rohlf. 1995. Biometry: the principles and practices of statistics in biological research, 3rd ed. W.C. Saunders Publishers, New York, USA.

Sprague, J.B. 1973. The ABC's of pollutant bioassay using fish. Biological Methods for the assessment of water quality, ASTM STP 528, American Society for Testing and Materials, pp 6-30.

Stout, J.D. 1980. The role of protozoa in nutrient cycling and energy flow. Adv. Microb. Ecol. 4: 1-50.

Stumm, W. and J.J. Morgan. 1996. Aquatic chemistry: Chemical equilibria and rates in natural waters, 3rd ed. John Wiley and Sons, Inc., New York, USA.

Tebo, L.B.,Jr.. 1985. Technical considerations related to the regulatory use of multispecies toxicity tests. In J. Cairns, Jr., ed. Multispecies toxicity testing. Pergamon Press, N.Y. pp 19-26.

Toussaint, M.W., T.R. Shedd, W. H. van der Schalie and G. R. Leather. 1995. A comparison of standard acute toxicology tests with rapid-screening toxicity tests. Environ. Toxicol. Chem. 14: 907-915.

United States Environmental Protection Agency (USEPA). 1986. Quality criteria for water. USEPA, Office of Water, Washington, D.C.

United States Environmental Protection Agency (USEPA). 1994. Federal Insecticide, Fungicide and Rodenticide Act (FIFRA); Good Laboratory Practice Standards. Proposed Rule. 40 CFR; Federal Register.. 
Verschueren, K. 1983. Handbook of environmental data on organic chemicals. Van Nostrand Reinhold Company, New York, USA.

Wolfaardt G.M., J.R. Laurence, J.V. Headly, R.D. Robarts and D.E. Caldwell. 1994. Microbial exopolymers provide a mechanism for bioaccumulation of contaminants. Microbial Ecology. 27: 279-291.

Yoshioka, Y., Y. Ose and T. Sato. 1985. Testing for the toxicity of chemicals with Tetrahymena pyriformis. Sci. Tot. Environ. 43:149-157. 


\section{APPENDIX A}

In addition to the final test methods previously listed, several preliminary experiments were performed which were essential to the success of the toxicity tests. This section describes those experiments.

\section{Growth}

The objectives of these experiments were two-fold: 1 ) to determine the minimal dilution of Sonneborn's medium that would supply enough nutrients for adequate growth and 2) determine average growth after a 24 and 48 hour test periods.

Tests were set up following the procedures for the toxicity test, except no toxicants were added (so all wells were "controls") and each test well contained a total of $1 \mathrm{ml}$. The three dilutions of Sonneborn's media tested were $10 \%, 5 \%$ and $1 \%$. All media were autoclaved prior to use. After 24 hours, the wells were counted and cell number recorded. Cells were then refreshed with $100 \mu \mathrm{l}$ of media $(10 \%, 5 \%$, or $1 \%)$ and counted again 24 hours later ( 48 hour total time). This experiment was repeated several times.

After both 24 and 48 hours, growth in the $10 \%$ medium was the highest, followed by $5 \%$. Little to no growth occurred in $1 \%$ Sonneborn's. In a 24 hour period, growth averages in $10 \%$ Sonneborn's medium ranged from 597 cells $( \pm 29.9)$ 1474 cells $( \pm 285), 5 \%$ ranged from 288 cells $( \pm 67)-637$ cells $( \pm 141), 1 \%$ averages 
extended from $0-125$ cells $( \pm 38)$. Counting the next day generally revealed higher cell numbers. One minor test indicated that $3 \%$ did not yield adequate growth. From this, it was determined that $10 \%$ and $5 \%$ Sonneborn's dilutions generally yielded a high enough cell count to perform toxicity testing.

\section{Variability}

Because the 24 well plates contain wells which are in different "positions" (i.e., middle of the plate, edges) and the toxicity test would most easily be set up in a nonrandom fashion (to avoid confusion of which test wells were which), preliminary tests were conducted to ascertain variability between wells in a single plate.

One full tissue culture plate test ( 24 wells) was performed with $10 \%$ Sonneborn's. Other tests were conducted using half of a plate (12 wells) with $10 \%$ and 5\% Sonneborn's. All media was autoclaved before use and total media and culture volume always equaled $1 \mathrm{ml}$. The test period was 24 hours. An ANOVA procedure was performed on the data obtained to determine if significant differences occurred between wells.

Growths for all tests were high over a 24 hour period. ANOVA results showed no significant differences between wells of any of the plates. Growth means and standard deviations for the 12 well test were: $10 \%, 1047 \pm 270$ cells; $5 \% 910 \pm 61$ cells. In the 24 well plate growth and standard deviations were 860 cells \pm 122 . 


\section{Bacteria}

The use of the food source Klebsiella pneumoniae was necessary for the tests conducted in the inorganic minimal salts media. Experimentation with methods relating to bacteria were investigated before a standard method was found.

When tests first began, bacteria were grown in flasks of $10 \%$ Sonneborn's media. Growth was slow and it was found that adding a few drops of peptone increased growth rates rapidly. Optical densities were not taken; growth increase was simply determined on the visual turbidity of the culture. If the culture was cloudy, 100 $\mathrm{ml}$ (divided into two $50 \mathrm{ml}$ tubes) was spun in the ultracentrifuge at approximately 13,000 RPMs for 20-30 minutes. Then the liquid was decanted and the pellet was resuspended in 10-15 ml sterile minimal salts media. Tubes were covered with parafilm wax and vortexed until adequately mixed. This bacterial mixture was then distributed as media and the food.

There are many problems with this method. First, since the exact amount of this slurry was distributed based on the calculations of toxicant, media, and cell volume, this quantity, and thus the amount of bacteria, varied per concentration (i.e., less bacteria would be in high concentrations where more compound stock was added). Second, the bacteria were centrifuged from liquid media which may have contained other organisms. The number of bacteria varied from test to test. Lastly, this method would be impractical for use in the field and also requires constant bacterial culturing. The method of growing the bacteria on agar plates, scraping, and freezing (described in 
the methods section) is much more conducive to the principles of rapid-screening toxicity testing.

In order to further standardize the addition of $K$. pnuemoniae, investigations were done to determine the approximate number of bacteria needed to sustain $C$. inflata for 24 hours. Because no more than $200 \mu 1$ of $C$. inflata cells were ever added to each well, a fixed volume of $200 \mu \mathrm{l}$ bacteria would also be added to each well. A test was set up using $200 \mu \mathrm{l}$ of varying optical densities (OD) of bacteria in cach wcll. Bacteria were prepared in the same manner described in the methods, and after optical density was read, $1 \mathrm{ml}$ of the bacteria sample was fixed (10:1) with $10 \%$ buffered glutaraldehyde (GTA). Minimal salts media, ciliates and $200 \mu \mathrm{l}$ of bacteria were added to two wells. The slurry was then diluted and the process was repeated. Twenty-four hours later the wells were inspected for growth. It was determined that the lowest OD for adequate growth was approximately $0.2(400 \mathrm{~nm})$.

The fixed samples of $K .$. pnuemoniae at this optical density were counted by epifluorescence staining. (All bacterial counting was done by Sara Carlsen). The samples were filtered on sterilized equipment, stained with 4',6-diamidino-2phenylindole (DAPI). After filtration, filters were placed on a cleaned slide and air dried. Counting was done under fluorescence at 1000X. Organisms were enumerated by counting all bacteria occurring in randomly selected grids of a standard Whipple Grid. A minimum of 10 grids were counted per slide. Calculations determined the 
average number of cells per $\mathrm{ml}$ to be $3.2 \times 10^{7}$. Thus the $200 \mu \mathrm{l}$ food source added to each well in these toxicity tests contained approximately $6.8 \times 10^{6} \mathrm{~K}$. pnuemoniae. 
APPENDIX B

This is a description of the chemical methods used by Coffey Laboratories, Inc. to analyze stock concentrations.

CFR 200.7 - cadmium, copper, sodium, zinc

This method is used to determine concentration of metals and trace elements by inductively coupled plasma-atomic emission spectrometry. Measurement of atomic emission was done by an optical spectrometric technique. This analysis was used for cadmium, copper, sodium (for SDS) and zinc (USEPA 1994). Currently there is no good way to directly measure SDS concentration. Hence, sodium is measured by this method and SDS is then calculated from the molecular formula of SDS (Harvey Jackson, Coffey Laboratories, pers. comm).

\section{CFR 604 - PCP}

This method involves flame ionization detector gas chromatography (FIDGC) and can be used in the determination of PCP. A gas chromatograph/mass spectrophotometer (GC/MS) is used for confirmation of the results (USEPA, 1994). 
EPA 614 - malathion

This is a gas chromatographic (GC) method used to detect organophosphorous pesticides such as malathion. A measured volume of sample is solvent extracted w/ $15 \%$ methane chloride in hexane. The extract is then dried and concentrated. GC is performed by flame photometric (FP) or thermionic bead gas chromatography (Pressley and Longbottom, 1982a).

EPA 615 - 2,4-D

A GC method used to determine 2,4-D in solution. A measured volume of sample is acidified. Acid herbicides and their salts are extracted with ethyl ether. Derivatives are hydrolyzed with potassium hydroxide and the extra organic material is then removed with a solvent wash. The remaining extracted acids are converted to their methyl esters with diazomethane. Excess reagents are removed and esters are determined by electron capture (EC) gas chromatography. (Pressley and Longbottom, 1982b).

SM 4500, A-D - ammonia

This is a series of methods used to determine the concentration of ammonia in an aqueous sample. Section A discusses selection of methods, possible interfaces and proper storage of samples (acidification to $\mathrm{pH}<2$, and storage at $4^{\circ} \mathrm{C}$ ). Section $\mathrm{B}$ describes a preliminary distillation step, which is necessary to complete prior to 
performing method C. Preliminary distillation involves buffering the sample at $\mathrm{pH} 9.5$ (to decrease hydrolysis of organic nitrogen compounds) and distillation into a solution of boric acid for the titrimetric method (C) or into a solution of $\mathrm{H} 2 \mathrm{SO} 4$ for the ammonia-selective electrode method (D). Coffey Laboratories used methods C and D to detect ammonia in stock sample. Method C, the titrimetric method, involves titration of ammonia in distillate with a standard titrant until the indicator is a pale lavender color. Concentration of ammonia is then calculated mathematically. The ammonia-selective electrode method uses a hydrophobic gas-permeable membrane to isolate the sample solution from an electrode in an internal solution of ammonium chloride (APHA, 1989). Un-ionized ammonia was calculated and corrected for $\mathrm{pH}$ and temperature (USEPA, 1986) 